\title{
How Much Do Sources of Happiness Vary Across Countries? A Review of the Empirical Literature
}

\author{
Olga Stavrova
}

Published online: 8 May 2019

(C) The Author(s) 2019

\begin{abstract}
This article presents a review of empirical research exploring cross-national differences in the correlates of subjective well-being (SWB). I start by giving an overview of the concept of SWB across psychological, sociological, and economic literature. Measures of SWB have good cross-cultural validity, yet there is currently little consensus regarding the cultural universality of the definition of happiness. An overview of existing empirical literature points toward robust crossnational differences in mean levels of SWB that are associated with national differences in wealth and other socioeconomic, political, and cultural factors. The degree to which individual-level variables are associated with SWB is also subject to crossnational variations. Many individuals' characteristics contribute to happiness to the extent that they are beneficial, socially desirable, and aspired to in a particular sociocultural context. These results are discussed in light of two theoretical approaches (institutional and fit hypotheses). Directions for future research are proposed.
\end{abstract}

Keywords Life satisfaction - Cross-national comparitive research · Subjective well-being $\cdot$ Culture $\cdot$ Person-culture fit

\section{Internationale Unterschiede in den Einflussfaktoren auf das Glück: Übersicht über die empirische Literatur}

Zusammenfassung Dieser Artikel stellt eine Übersicht der empirischen Forschung über internationale Unterschiede in den Korrelaten des subjektiven Wohlbefindens (SWB) dar. Zuerst wird eine Übersicht der Konzeptualisierung und Operationalisie-

\footnotetext{
O. Stavrova $(\square)$

Department of Social Psychology, Tilburg University PO Box 90153, 5000 LE Tilburg, The Netherlands

E-Mail: O.Stavrova@uvt.nl
} 
rung des Konzepts SWB in der psychologischen, soziologischen und ökonomischen Literatur gegeben. Obwohl es in der Glücksforschung keine Übereinstimmung über die interkulturelle Universalität der Definition von Glück gibt, ergaben die Messinstrumente von SWB eine gute interkulturelle Validität. Ein Überblick empirischer Studien zeigt robuste internationale Unterschiede in den Durchschnittswerten von SWB, die mit nationalen Unterschieden im Wohlstand und anderen sozioökonomischen, politischen und kulturellen Faktoren zusammenhängen. Der Zusammenhang zwischen Glück und individuellen Merkmalen unterliegt ebenfalls internationalen Unterschieden. Individuelle Faktoren tragen zum höheren SWB insofern bei, als sie in einem bestimmten soziokulturellen Kontext sozial erwünscht und angestrebt sind. Die Ergebnisse werden im Licht von 2 theoretischen Ansätzen (institutionelle Hypothese und Person-Umwelt-Passungstheorie) diskutiert. Es werden Vorschläge für zukünftige Forschung gemacht.

Schlüsselwörter Lebenszufriedenheit · International-vergleichende Forschung · Subjektives Wohlbefinden · Kultur · Person-Umwelt-Passung

\section{Introduction}

The question of the nature and causes of human happiness has been a source of major interest in philosophy since antiquity, with different schools of thought offering different answers (McMahon 2006). In contrast to philosophy, it is only since the middle of the twentieth century that social scientists have discovered this research field. Since then, research on happiness, or subjective well-being (SWB), as this concept is often referred to in the social sciences, has been very fruitful, and attracted scholars from diverse disciplines, including psychology, sociology, and economics, who have published more than 80,000 articles on that topic in total over the last 30 years (according to the Web of Science).

Most of this work has been dedicated to revealing factors that contribute to a higher vs. a lower SWB. Some studies have focused on individual characteristics, such as personality traits, values, and beliefs or life circumstances. Others explored contextual or country-level predictors, such as cross-national differences in social policies, socioeconomic conditions and culture. Finally, a third group of studies combined the investigation of individual- and country-level factors exploring how they come together to affect individuals' happiness. Studies exploring individuallevel predictors probably represent the largest portion of the literature and have been the target of several review papers in psychology (Diener et al. 1999; Lyubomirsky et al., 2005a, b). Studies exploring national-level predictors have been the major focus of sociological and economic literature on SWB and have also been reviewed before (Di Tella et al. 2003; Frey and Stutzer 2005). Yet, there have been no reviews of the third stream of empirical research, the one that combines the examination of individual- and country-level predictors of SWB. Therefore, the present review focuses on this third group of studies. Nevertheless, to put these studies into context, I also include an overview of empirical studies that examined individual- and country-level predictors independently of each other. I will start by discussing existing 
conceptualizations, definitions, and measurements of the concept of SWB, including the question of its cross-cultural validity (see also Cieciuch et al. 2019). I will then proceed to present an overview of empirical findings pertaining to individual- and country-level predictors, as well as their joint effects on SWB. Finally, I will discuss the results in the light of existing theories and outline directions for future research.

\section{The Concept of Subjective Well-being}

Probably due to the interdisciplinary nature of SWB research (it is an active area of research across diverse disciplines, mainly including psychology, sociology, and economics), there are currently dozens of concepts that are studied under the umbrella term of subjective well-being: life satisfaction, avowed happiness (Wilson 1967), subjective happiness (Lyubomirsky and Lepper 1999), authentic happiness (Seligman 2002), affect balance (Bradburn 1969), experienced utility, and objective happiness (Kahneman 2000), to name but a few.

Even though research on SWB is largely interdisciplinary in nature, it has long been dominated by psychologists. This is not surprising, as SWB is an individuallevel concept that deals with differences in individuals' subjective perception and evaluation of reality; and the way people see reality is the core business of psychology, a science of the human mind. In contrast, despite the rising level of interest in the concept of happiness in sociology and economics, it is still rarely discussed in the respective textbooks and journals (Veenhoven 2008). This relative lack of interest has been explained by these disciplines' main interest in understanding societal problems rooted in objective reality or conditions, rather than understanding how people feel about reality and about their conditions, and why (Veenhoven 2008). Accordingly, the most elaborate conceptualization of happiness stems from psychological literature and will be the focus in the present review. At the same time, as I explore an interplay of individual and contextual (country-level) predictors of happiness, and the latter have been almost exclusively the focus of sociology and economics (with the exception of cross-cultural research), I will provide an overview of how happiness is conceptualized in these disciplines as well.

\subsection{The Concept of SWB in Psychology}

The most widely accepted conceptualization of SWB in psychology was proposed in the 1980s by Ed Diener, who also coined this term. SWB was defined as "a general area of scientific interest, rather than a single specific construct" (Diener et al. 1999 , p. 277), with life satisfaction and affect representing the most widely studied concepts within the field of subjective well-being. Life satisfaction represents a cognitive aspect of SWB; it refers to individuals' evaluation of how close their life is to what constitutes an ideal life in their view. Affect represents the emotional component of SWB. It is typically operationalized as frequency and intensity of positive and negative emotions experienced during the last several weeks (Diener 1984; Kahneman and Deaton 2010). 
Both the cognitive and affective components of SWB are subjective and depend on individuals' personal evaluation and judgment. Also, they are both hedonic, rather than eudaimonic, in nature. Current psychological literature on well-being distinguishes between its hedonic and eudaimonic components (Ryan and Deci 2001). Eudaimonic well-being is grounded in the philosophy of Aristotle, who suggested that a life of virtue and realization of one's potential constitutes true happiness (eudaimonia). The Aristotelian conception of happiness has been further developed by humanistic and positive psychologists (Ryff 1989; Seligman 2002). Instruments measuring eudaimonic well-being typically include such concepts as meaning and purpose, personal growth and development, rather than mere satisfaction. For example, Ryff (1989) considers happiness (psychological well-being) as consisting of six dimensions: autonomy, personal growth, mastery, positive relatedness, life purpose, and self-acceptance.

In contrast, hedonic - both cognitive and affective-well-being emphasizes individuals' global evaluation and feeling regarding their lives. SWB is retrospective in nature, meaning that measures of life satisfaction or affect represent memorybased reports. Although such retrospective reports of happiness do not completely overlap with moment-to-moment happiness (e.g., measures of happiness collected during different activities and times of the day) (Fredrickson 2000; Redelmeier and Kahneman 1996), they are important as they often represent the basis of individuals' decision making. For example, it is the retrospective, stored-in-memory judgment of happiness one experienced in a particular restaurant that is likely to affect one's decision to visit this restaurant again (Stavrova 2014).

\subsection{The Concept of SWB in Sociology and Economics}

Sociological research has started showing an interest in the studies of happiness since the 1980s. Similar to psychology, a variety of terms referring to happiness have been used by sociologists as well. While some of these terms overlap with the ones used by psychologists, others are new and denote the particularities of the use of the concept in sociology in general. For example, while the term "happiness" and "subjective well-being" are used by both psychologists and sociologists as an umbrella term, sociologists see it as a synonym of "quality of life" and "individual and social welfare" (Veenhoven 2012). Regardless of these differences, the definition of happiness adopted in sociology is quite similar to the psychological one: happiness is defined in sociology as "the degree to which an individual judges the overall quality of his/her own life-as a whole favorably" (Veenhoven 1984). Yet, in contrast to psychologists, who differentiate between the cognitive and the affective components, sociologists see life satisfaction and happiness as a combination of a "cognitive comparison with standards of the good life (contentment) and affective information from how one feels most of the time (hedonic level of affect)" (Veenhoven 2008). In a tradition of social constructionist theories (Berger and Luckman 1966), sociologists share a constructionist view of happiness, assuming that happiness represents individuals' construction of reality, which is largely determined by comparative thinking: people are happy as long as their life meets their expectations and is not worse than a neighbor's life (Veenhoven 2008). As the main measurement 
instrument, sociological research typically uses a single happiness item that directly asks individuals how happy they are with their lives as a whole.

Interestingly, this very measure of happiness is also quite often used in economics (Frey and Stutzer 2002a; 2005). The concept itself is however considered in a quite different light. In contrast to the social constructionist view shared by sociologists (and psychologists, although they would not call it that), economists use happiness as a tool to measure the desirability of objective reality, or in other words, for economists, happiness represents a measure of utility (Frey and Stutzer 2014). Economists' interest in happiness is just a result of their attempts to find the best operationalization of the utility that individuals derive from using different products, institutional or social policy changes (Di Tella et al. 2003; Di Tella and MacCulloch 2006; Frey and Stutzer 2002a, b).

\subsection{SWB Measurement}

A variety of reliable and valid instruments have been designed to assess SWB and its different components. One of the most widely known instruments used to measure life satisfaction in psychology and sociology is the Satisfaction With Life Scale (Diener et al. 1985). It consists of five items and has a high degree of reliability and external validity (Pavot and Diener 1993). It shows a high level of self-informant consistency (Schneider and Schimmack 2010) and converges with objective measures of satisfaction (e.g. smiling behavior, use of negative emotion words in texts) (Liu et al. 2015; Settanni and Marengo 2015). It has also been shown to have high temporal stability (0.54 within 4 years; Diener et al. 2013), showing that -in contrast to what some studies have suggested (Schwarz 1990, but see Yap et al. 2016) — satisfaction with life is not a momentary assessment that is potentially subject to framing, item order, or weather effects (Diener et al. 2013; Pavot and Diener 2008).

Most large-scale cross-national studies typically rely on a single-item scale of life satisfaction, asking participants to indicate how satisfied they are with their lives overall (a 10-point Likert scale is usually used). This single-item measure of life satisfaction has been shown to strongly correlate with the Satisfaction With Life Scale and to have good external validity as well (Cheung and Lucas 2014; Jovanović 2016). Due to its brief form and ease of use, it has been included in many large-scale cross-national surveys. As a result, most cross-national findings on life satisfaction so far are based on the data using this measure.

Regarding the affective component of SWB, a number of measures have been developed as well, with Bradburn's Affect Balance scale (Bradburn 1969) and Positive and Negative Affect Schedule (PANAS; Watson et al. 1988) being the scales used most often. These measures assess the frequency of experiencing a series of positive and negative emotions over the past 4 weeks.

Cognitive (life satisfaction) and affective measures of SWB show moderate to strong correlations with each other (Diener et al. 1999), but do demonstrate distinct patterns of correlations with other constructs. For example, while higher income is positively related to life satisfaction, it does not predict more positive emotions (Kahneman and Deaton 2010). On the other hand, fulfillment of psychological needs, 
such as social affiliation, respect, and autonomy, is a stronger predictor of affect than it is of life satisfaction (Diener et al. 2010).

Importantly, existing SWB measures show a good level of cross-cultural validity. For example, a couple of studies showed that instruments developed to measure SWB in the West show acceptable levels of reliability, convergent and discriminant validity in other cultural contexts (Whisman and Judd 2016; see also Cieciuch et al. 2019). For example, the Satisfaction with Life Scale, which was developed for use in American samples, showed the same factor structure in samples of Serbian adolescents (Jovanović 2016), elderly Mexican people (López-Ortega et al. 2016), Korean elementary school children (Lim 2015), as well as adolescents and young adults in Portugal (Silva et al. 2015) and Italy (Di Fabio and Gori 2016). Also, reports of life satisfaction converge with more objective validity indicators, such as reports of positive vs. negative events, not only in American but in other cultures as well (Balatsky and Diener 1993).

Somewhat less consensus exists with respect to the extent of cross-cultural differences in folks theories of happiness, that is, lay beliefs about the nature and sources of happiness. On the one hand, a stream of literature in cross-cultural psychology tends to emphasize cross-cultural differences in lay (and even in dictionary, Oishi et al. 2013) definitions of happiness (Uchida and Kitayama 2009). These studies showed that North American vs. East Asian and East European participants think about happiness differently, with the former seeing it exclusively positively, and the later having a more ambivalent attitude towards happiness, including its negative aspects, such as the fact that it does not last long and may even cause envy on the part of others (Joshanloo et al. 2014). At the same time, cross-cultural commonalities in lay beliefs about happiness have been shown as well. For example, a recent exploration of lay definitions of happiness showed a certain degree of similarity, with an emphasis on inner harmony being considered central to happiness across the twelve countries studied, including the U.S., India, as well as some Eastern European and Latin American countries (Delle Fave et al. 2016).

While cognitive and affective components of SWB might be equally important, disciplines differ in what component they mostly focus on, with psychological research being interested in both, while studies conducted in sociology and economics are mostly restricted to life satisfaction or overall happiness (forgoing the distinction between cognitive and affective components altogether). As a result, most largescale cross-national datasets include a measure of life satisfaction ("Taking all things together, how satisfied you are with your life these days?") and overall happiness ("Taking all things together, would you say you are very happy, quite happy, not very happy, not at all happy?"), but no measures of affective well-being, and most findings on cross-cultural variability in mean levels and correlates of SWB, are restricted to life satisfaction and overall happiness.

\section{Individual Predictors of SWB}

At the individual level, personality has been shown to be one of the strongest predictors of happiness (Lyubomirsky, Sheldon and Schkade 2005). In fact, differences in 
stable individual dispositions are assumed to account for about half of the variance in SWB (Lyubomirsky et al., 2005b). Among the Big Five personality traits, neuroticism has been shown to be the strongest negative predictor of life satisfaction (Steel et al. 2008). Neurotic individuals are moody, experience frequent mood swings, get upset and stressed out easily, and respond to negative stimuli with greater anxiety. It comes as no surprise that neurotic individuals tend to report lower levels of life satisfaction and happiness.

Besides neuroticism, extraversion and conscientiousness typically show an independent positive association with SWB (Hayes and Joseph 2003; Lucas et al. 2000; Steel et al. 2008; Suldo et al. 2015). Extraverted individuals feel comfortable being around other people, start conversations easily, and like social attention; they are talkative and easy going. As a result, extraverted individuals are more likely to develop a sense of belonging, have more friends and acquaintances, are more likely to report high-quality relationships with others, less likely to feel lonely and socially excluded-all these attributes being important components of a happy life (Diener and Ryan 2009). In addition, social perception studies show that extraverted individuals are also perceived as being more likeable and preferred as communication partners and friends (Feiler and Kleinbaum 2015). What we see here is that higher levels of extraversion make one's social life easier and satisfy one's need to belong (Baumeister and Leary 1995), thus, representing an important factor contributing to happiness.

Conscientious individuals like order, pay attention to details, follow schedules and plans, are dutiful and responsible. Given that all these characteristics facilitate goal achievement and success, conscientious individuals report higher SWB than their less conscientious counterparts do (Hayes and Joseph 2003; Suldo et al. 2015). Other dispositional traits reflecting one's strength of will, such as the trait of self-control, as well as one's perception of control over one's life, show consistent positive associations with SWB as well (Hofmann et al. 2014; Lachman and Agrigoroaei 2010). Importantly, even though early research has almost unanimously assumed that differences in these basic personality traits result in different levels of SWB (Diener et al. 2003), more recent studies have shown that SWB can also affect personality development (Specht et al. 2013). Using the longitudinal data from Germany (German Socio-Economic Panel Study), Specht and colleagues (2013) showed that individuals with a higher (vs. lower) baseline level of life satisfaction were more likely to become more conscientious and less neurotic over time.

Finally, individuals' feelings and beliefs regarding the "self" represent another factor influencing well-being. Specifically, higher levels of self-esteem are positively associated with life satisfaction (Cheng and Furnham 2003). Individuals with high self-esteem are less likely to experience stressful life events (Orth and Luciano 2015) and are more likely to be liked and respected by others (Reitz et al. 2016).

Individual differences in goals, values, and beliefs are associated with SWB as well. The importance of goal attainment has been acknowledged in psychology since Maslow's pyramid of needs (Maslow 1943). Goals have also been seen as a crucial component of happiness in sociological theories. For example, the Social Production Function Theory (Ormel et al. 1999) postulates that people's SWB is contingent on 
achieving five universal goals (stimulation, comfort, status, behavioral confirmation, and affection).

Conversely, another stream of literature suggested that it does not matter much whether or not goals are attained, but rather it is the type of goals people pursue that is crucial for SWB. For example, pursuing avoidance goals (e.g. not failing an exam) is associated with lower SWB, while endorsing approach goals (e.g. getting a great grade in an exam) is related to higher SWB (Elliot et al. 1997). Pursuing materialistic goals was shown to lead to a lower SWB (Kasser and Ryan 1993), and pursuing goals emanating from intrinsic rather than extrinsic motivations is related to an increased SWB (Sheldon and Kasser 1998). Research into values and SWB has also backed up the importance of the self-determination view (Ryan and Deci 2001). Specifically, it has been shown that self-direction, stimulation, and achievement values are positively related to positive emotions, whereas security, conformity, and tradition values are negatively associated with positive emotions (Sagiv and Schwartz 2000).

Finally, beliefs about the world have also been shown to affect happiness. For example, individuals who believe in a just world are more likely to report higher life satisfaction and more frequent positive affect than their counterparts with a lower level of belief in a just world (Correia et al. 2009; Lucas et al. 2013). Furthermore, conservative political ideology (Napier and Jost 2008), sexist ideology (Hammond and Sibley 2011), religious beliefs (Diener et al. 2011), and interpersonal trust (Tokuda et al. 2010) are also often cited as sources of life satisfaction. However, as most of these studies are based on correlational data, it remains unclear whether holding certain types of beliefs makes one happier and more satisfied, or whether happy and satisfied people are more likely to endorse certain types of beliefs.

Sociodemographic factors, life circumstances and events have been shown to explain individual differences in happiness as well. The findings indicate that having a job (Carroll 2007), earning good money (Luhmann et al. 2011), as well as being married or having a long-term partner (Kim and MacKenry 2002) are all positive predictors of SWB. In contrast, unemployment, divorce, widowhood, and poverty contribute to a lower SWB (Lucas et al. 2004; Williams and Dunne-Bryant 2006). However, these effects are probably bidirectional such that life satisfaction can "predispose" individuals to certain life events. For example, prospective studies have shown higher levels of baseline life satisfaction to be associated with higher chances of marriage and lower risks of divorce and unemployment (Luhmann et al. 2013). It should be noted that the explanatory power of sociodemographic factors is very small compared to that of the Big Five and other personality traits. According to Lyubomirsky et al. (2005b), while personality accounts for about $50 \%$ of variance in SWB, individual differences in sociodemographics only explain about $10 \%$.

At a theoretical level, the relative importance of personality predictors provides support to the so-called top-down theories of happiness, according to which individuals' stable predispositions with a large genetic component shape individuals' happiness level. This view has also been expressed in the set-point theories of happiness (Headey and Wearing 1992). According to these theories, individuals have a genetically determined default level of happiness. Different life circumstances and behaviors may change it in the short run, reducing or increasing individuals' 
happiness that will however ultimately return to its set point. These theories have been supported by a strong temporal stability that happiness measures are known to possess, as well as by surveys of twins. For example, one highly cited twin study supported the set-point assertion but showed that happiness levels in monozygotic twins correlate at 0.40, and in dizygotic twins at just 0.08 (Lykken and Tellegen 1996). Similarly, long-term panel studies have shown the test-retest correlation of life satisfaction to reach high values (around 0.50) across decades (Schimmack and Oishi 2005).

In contrast, the bottom-up theories assume that happiness is a result of being in a beneficial vs. threatening environment or experiencing positive as opposed to negative events. In other words, "a happy individual is happy precisely because he or she experiences many happy moments" (Brief et al. 1993). Consistent with this idea, large-scale panel studies have shown happiness to be subject to major life events (Lucas 2007), thereby questioning the postulates of the set-point theory. Not all events are capable of affecting individuals' default level of happiness, though: while periods of unemployment were shown to leave long-term "scarring" effects, the happiness brought about by getting married was short-lived (Lucas 2007; Lucas et al. 2004).

While many life events lie outside individuals' control and responsibility, there are ways in which, researchers believe, people can still shape their own happiness. Specifically, individuals can change their SWB through "effortful activities". Indeed, individual differences in everyday behavior are assumed to account for about $40 \%$ of variance in SWB (Lyubomirsky et al. 2005b). What are the activities that promote happiness?

One of these activities is prosocial behavior. The idea that prosociality is an important source of happiness harkens back to ancient philosophy, with Aristotle and Plato believing that a life of virtue is the only possible route to happiness. Recent psychological and sociological research has provided support for this idea from Antiquity, showing that altruistic behavior, volunteering and charity donations are associated with increased life satisfaction (Aknin et al. 2013; Dunn et al. 2008; Schwartz et al. 2003; Stavrova et al. 2013b). Importantly, the benefits of altruism were supported in experimental research as well. For example, Aknin et al. (2013) provided their participants with a small sum of money and instructed half of them to spend it on themselves and the other half to spend it on others. By the end of the day, the members of the latter group (prosocial spending) reported higher happiness levels than those in the former group (selfish spending).

Not only prosocial, but also merely social activities have been recognized as a source of SWB. Experience sampling studies (in these studies, participants are signaled with a smartphone application several times per day within a certain fixed time period, such as a week, and asked to fill in a small survey about their current experiences, thoughts, and feelings; this method makes it possible to study individuals' daily experiences without relying on their memory) have shown that individuals report the lowest positive affect when they are alone. In fact, people are happier when they are with their clients and bosses than just alone (Kahneman 2000). Different measures of social engagement, the presence of friends and a romantic partner were all associated with higher levels of SWB (Lucas and Dyrenforth 2006). 
Finally, recent studies suggest that genetic and environmental factors (life circumstances, life events, the activities one chooses to engage in) are not independent of each other (Plomin 1994). For example, in a theory of person-situation transactions, individuals self-select into certain environments based on their personality predispositions (Caspi et al. 1989). To give an example, neurotic individuals are more likely to withdraw from social events, thus, further exacerbating their unhappiness. As a result, individuals' life outcomes (including happiness) represent a joint product of both genetic predispositions (e.g. personality) and environmental factors. This enables characteristics of one's national context to be recognized as being particularly important "environmental" factors. The following section explores existing findings on country-level predictors of SWB.

\section{Country-level Predictors of SWB}

Countries show substantial differences in average SWB levels. For example, analyses combining individual- and country-level predictors suggest that regional and national differences explain large amounts of variation in individuals' life satisfaction (Bonini 2008). Also, national SWB scores show a surprisingly high level of temporal stability. For example, in a 30-year period, the Japanese level of life satisfaction did not substantially deviate from a 6 on a 10-point scale, whereas that of the Danes fluctuated around an 8 (Veenhoven 1993). Which country-level characteristics explain differences in national levels of SWB?

Multiple studies converge on differences in national wealth as one of the most important country-level variables related to life satisfaction (Diener et al. 2003). Correlations between gross domestic product (GDP) and the national level of life satisfaction are typically in the range of $0.50-0.60$, with individuals living in wealthier countries reporting higher life satisfaction compared to individuals in poorer ones (Di Tella et al. 2003). Interestingly, the associations between wealth and life satisfaction at the individual level are substantially smaller: individuals' wealth (e.g. personal income) correlates with their life satisfaction at approximately 0.10 . One explanation of why wealth seems so important at the country level is that wealthy nations typically score higher on a wide range of other characteristics that have been shown to have beneficial consequences for their citizens' SWB as well: political freedom, civil rights, good governance, low crime rates and low social inequality (Dorn et al. 2007; Oishi et al. 2011; Ott 2011). Although there have been attempts to disentangle the effects of these different factors, they have been largely unsuccessful due to strong intercorrelations between the predictors and a small number of countries available for the analyses (Diener et al. 2003).

Besides socioeconomic and political differences, cultural dimensions have been shown to explain country-level differences in SWB as well. Among them, individualism vs. collectivism and uncertainty avoidance showed the most consistent associations with SWB. Individualism (vs. collectivism) represents one of the most widely studied and recognized dimensions of culture (Hofstede 2001; Markus and Kitayama 1991; Triandis 1995). Individualistic cultures are characterized by an emphasis on individuals' (vs. groups') needs and values, values of autonomy, and 
independence, whereas collectivistic cultures are defined by prioritizing groups' values and well-being over those of individuals, security, and interdependence values and a stronger differentiation between in-groups and out-groups. People in collectivistic cultures tend toward an interdependent self-concept, defining themselves primarily as members of social groups. Individualism vs. collectivism, as well as many other dimensions of culture, have been quantified. That is, nearly a hundred national cultures have been assigned an individualism-collectivism score (as well as scores on other cultural dimensions such as uncertainty avoidance), which represents nationally aggregated individuals' responses to items yielding their preferred values, norms, attitudes, and behaviors. This has allowed researchers to explore the potential associations between cultural dimensions and SWB. As a result of this exploration, residents of individualistic countries were shown to score higher on life satisfaction and positive affect than residents of collectivistic countries did (Diener and Suh 2000; Hofstede 2001). Although this effect can be partly explained by the fact that individualistic cultures tend to be wealthier, it is consistent with different psychological perspectives highlighting the importance of freedom of choice and autonomy for well-being (e.g. the Self-Determination Theory; Deci and Ryan 2000; Ryan and Deci 2000).

The cultural dimension of uncertainty avoidance describes cultural differences in the tolerance of uncertainty and ambiguity (Hofstede 2001). While people in general show an aversion towards uncertainty, this is particularly so in cultures characterized by higher levels of uncertainty avoidance. Individuals in cultures with higher scores in uncertainty avoidance are particularly uncomfortable with uncertain and ambiguous situations, and rely on strict rules and regulations as a way of coping with uncertainty. In contrast, cultures with low scores on uncertainty avoidance show greater tolerance toward uncertainty; they perceive changeable environments and an uncertain future not as a threat but as an opportunity. Given that uncertainty is inherent to virtually any aspect of our lives, residents of cultures high in uncertainty avoidance tend toward lower SWB scores than cultures that are more tolerant of uncertainty (Hofstede 2001).

It is noteworthy that even though these studies examined the effect of culture as a macro-level characteristic, it is less clear whether the mechanism of these effects operates at a macro- or a micro- (i.e. individual) level. In fact, being part of an individualistic culture can strengthen an individual's SWB either because he/she is then more likely to hold an individualistic orientation him/herself or because living in an individualistic culture gives one more autonomy from others. Similarly, a country's level of uncertainty avoidance might be negatively associated with its citizens' happiness, either because the citizens are then more likely to be uncomfortable with uncertainty themselves or because being surrounded by individuals who are intolerant of uncertainty makes one's life stressful regardless of one's own uncertainty orientation. Examining the effects of these cultural orientations at both individual and country level would foster our understanding of these processes.

Even though no studies have undertaken this endeavor with respect to the dimensions of culture discussed above, several studies have attempted to differentiate between the effects of the same constructs measured at individual and country level in other areas. For example, it has been shown that more trusting individuals report 
higher levels of life satisfaction than their less trusting counterparts, and that residents of more trusting cultures score higher on life satisfaction than residents of less trusting cultures do (Tokuda et al. 2010). Importantly, the effects at the individual and the country level were independent of each other: individuals living in countries with a high level of social trust are happier than individuals living in countries with a lower level, regardless of their personal trust score (Tokuda et al. 2010). Similarly, individual, national, and regional levels of neuroticism were shown to be robust negative predictors of SWB (Rentfrow et al. 2008; Steel and Ones 2002). For example, Steel and Ones (2002) demonstrated a strong negative association between neuroticism and life satisfaction aggregated at the country level. This negative relationship was replicated at the state level in the U.S., such that states with a high aggregated neuroticism score tend toward a lower SWB than states with a lower level (Rentfrow et al. 2009). Most recently, multilevel analyses of individual neuroticism and regional neuroticism in Germany showed that living in a state that was neurotic was negatively related to life satisfaction, regardless of individuals' own neuroticism score (Stavrova 2015a). Regardless of how neurotic a person is, being surrounded by neurotic individuals (that is, living in a region with a high level of neuroticism) has a detrimental effect on one's happiness.

At the same time, some individuals' characteristics seem to affect SWB only when aggregated at the macro-level. For example, a series of studies have shown that an average level of education in cities was positively related to a city-average SWB, whereas the association between education and happiness at the individual level was negligible (Florida et al. 2013). Similarly, national IQ was shown to positively predict the happiness of nations, whereas between-individual differences in intelligence are not a robust predictor of individuals' SWB (Veenhoven and Choi 2012). Taken together, these results suggest that some individual characteristics do not affect SWB directly, but only when aggregated at a higher level (city, region, country), probably via shaping societal living conditions and cultural climates.

Finally, according to a number of psychological perspectives, country-level differences in SWB might be explained by cultural differences in self-enhancement and the cultural importance of happiness. One of the most robust findings in cross-cultural psychology is the variation in self-serving and self-enhancement motives and tendencies, with individualistic cultures showing stronger self-enhancement than collectivistic ones (Heine and Hamamura 2007). Multiple psychological studies have shown that people in individualistic cultures tend to consider themselves as scoring higher on a range of positive traits and as having better future prospects than most other people (Dunning et al. 2004; Weinstein 1980). Such self-serving biases have been shown to be less common in collectivistic cultures, suggesting that crosscultural differences in the mean level of SWB might be at least partly a result of a stronger self-enhancement tendency in individualistic (vs. collectivistic) nations.

Supporting this conclusion, several studies demonstrated that self-enhancement tendencies affect autobiographical memory (Ross and Qi 2010; Ross and Wilson 2002). Study participants in individualistic cultures tended to remember events that made them proud of themselves as being subjectively more recent than events that made them feel ashamed, while no difference was observed in East Asian participants (Ross and Wilson 2002). Following up on this finding, another study compared 
measures of happiness in U.S. and East Asian individuals that were either retrospective ("How satisfied were you with your life this week?") vs. immediate ("How satisfied were you with your life today?"), but averaged over seven days. The usual differences in life satisfaction between East and West emerged when retrospective but not immediate measures were used. In other words, when asked to report their satisfaction within the last week from memory, U.S. Americans were more satisfied than East Asians, although daily reports revealed no differences, suggesting that cross-cultural differences in mean levels of life satisfaction might be partly explained by cultural differences in self-enhancement and autobiographical memory biases (Oishi 2002). Hence, although cross-national differences in mean levels of SWB are large, temporally stable, and show consistent correlations with countries' socioeconomic, political and cultural characteristics, it remains to be explored to what extent these differences are "true" or just reflect cultural differences in indepth psychological processes, such as memory biases.

\section{A Joint Examination of Individual- and Country-level Predictors of SWB}

Countries might not only differ in mean levels of SWB, but also in its correlates. Are sources of happiness culturally universal, or do they vary across countries? And are there any systematic patterns in these variations?

In contrast to sociological research tradition, psychological research often tends to assume universality in its theory and findings (Oishi et al. 2009). This tendency is evident in the recently criticized propensity of psychological researchers to draw conclusions about human nature from data obtained from WEIRD (Western, Educated, Industrialized, Rich, Democratic) samples (Henrich et al. 2010), as well as in theories of universal human needs and motivation. For example, Maslow advanced the idea of universal needs as far back as in the 1940s - needs inherent to human nature (Maslow 1943). Striving for universality can be observed in later theoretical work as well. For example, Ryff's psychological model of well-being postulates the existence of six universal needs (autonomy, growth, relationships, purpose in life, environmental mastery, and self-acceptance), the fulfillment of which leads to wellbeing (Ryff 1989), whereas Deci and Ryans' self-determination theory advances the existence of three such universal needs (autonomy, competence, relatedness) (Deci and Ryan 2000).

While intuitively appealing, such a universalistic approach has been only partially supported by empirical research. Even though positive relationships, self-esteem and other presumably universal sources of SWB typically show positive associations with life satisfaction across cultures, the magnitude of such associations often differs (Diener and Diener 1995). Although substantial efforts have been directed at uncovering systematic patterns in these variations, theory building has lagged behind. I give below an overview of empirical findings and theoretical approaches aimed at explaining cross-national variations in correlates of SWB in sociology, economics, and psychology. 
Using the search terms "happiness or life satisfaction or subjective well-being" and "cross-national or cross-cultural" resulted in 1519 articles in academic journals in PsychINFO, PsychARTICLES, EconLIT and an additional 470 in Sociological Abstracts. A brief look at the listed articles showed that most of them do not explore cross-national variability in individual-level associations, but rather explore either predictors of SWB at the individual level or national differences in the mean level of SWB. Therefore, the search was refined by adding the term "multilevel" (as exploring cross-level interactions typically requires a multilevel analysis). This modification resulted in 54 articles in academic journals in PsychINFO, PsychARTICLES, EconLIT and an additional 12 in Sociological Abstracts. For this review, I selected empirical papers that explicitly indicated having explored both individual- and country-level predictors of SWB in the abstract. Further relevant empirical papers were detected via studying the literature cited in these articles as well as the literature that cited them. Finally, a number of relevant empirical papers - that were not detected using the search terms described above but that I was familiar with through my work-were considered as well. The list of reviewed papers is presented in the Appendix (Table 1). While this search strategy does not render the present review comprehensive, it nonetheless makes it possible to detect major theoretical and empirical trends in the literature.

An examination of the empirical work showed that most of the existing empirical results can be categorized as adopting one of two approaches: I describe the first one as the "institutional hypothesis", while the second one is typically referred to in the literature as the "fit hypothesis".

\subsection{The Institutional Hypothesis}

The theoretical reasoning behind most sociological and economic research exploring cross-national variability in correlates of SWB can be summarized as follows: individuals' characteristics contribute to happiness to the extent that macro-level conditions are favorable to individuals with these characteristics-what I refer to as the "institutional hypothesis". Below, I summarize research findings supporting (and refuting) the institutional hypotheses across different domains, including employment, family life, and health.

\subsubsection{Employment}

The adverse consequences of job loss for happiness and life satisfaction have been largely acknowledged in the literature (Carroll 2007). Cross-national studies in sociology and economics additionally explored whether labor market policies, including unemployment benefits and employment protection regulations, could mitigate the negative effect of unemployment. For example, Voßemer et al. (2017) studied the role of cross-national differences in labor market policies in shaping the well-being and health of unemployed individuals across 26 European countries. Consistent with the institutional hypothesis, they found that unemployed individuals were better off in countries with more (vs. less) generous unemployment benefits. This finding was further refined by Ochsen and Welsch (2012), who distinguished between the effects 
of employment protection policies and unemployment benefits, using the data from nearly 400,000 individuals in ten European countries, from 1975 to 2002. Their analyses showed that employment protection and a higher benefit replacement rate were positively associated with the life satisfaction of everyone, with employment protection being particularly appreciated by the employed but higher replacement rates - by the unemployed. Having said that, not all the studies supported the institutional hypothesis. For example, Eichhorn's (2014) analyses of the data from the European Values Study including 28 countries showed that the effect of unemployment on life-satisfaction was not moderated by unemployment benefits. In another study, a generous social policy regarding unemployment benefits has been shown to mitigate the negative effect of financial hardship on the SWB of self-employed individuals across 31 European countries (Annink et al. 2016), suggesting that the beneficial effect of supportive institutions might be more specific than previously assumed, at least with respect to unemployment benefits.

\subsubsection{Family Life}

Another type of social benefits that has been explored as a factor potentially contributing to the well-being of social groups in need of support are family and parental benefits. Most studies examining the effect of parenthood on SWB have shown that parents typically report lower SWB levels than childless individuals (e.g. Luhmann et al. 2012). Can the burden of parenthood be alleviated by welfare state support? Glass et al. (2016) showed that the negative effect of parenthood on happiness was weaker in countries with more (vs. less) generous welfare policies supporting families. It has been suggested that welfare state support directed at parents can compensate for the stress of parenthood, reducing the disparities in happiness between parents and nonparents (see also Hank and Steinbach 2019). Generous welfare state support has also been shown to mitigate the negative effect of being childless in old age. Specifically, Neuberger and Preisner (2017) used the data of the Survey of Health, Ageing and Retirement in Europe (including 19 countries) and the English Longitudinal Study of Ageing - both large-scale surveys including respondents aged 50 and older - to show that generous social benefits are associated with a higher SWB for childless elderly individuals.

\subsubsection{Health Care and Aging}

Another line of research explored the role of health care policies in mitigating the effect of ill-health on SWB (see also Pförtner et al. 2019). For example, KöötsAusmees and Realo (2015) used the data from 32 countries (using the data of the European Social Survey) and showed that even though the association between selfreported health status and life satisfaction is positive across countries, it was weaker in countries with higher (vs. lower) government spending on health care programs. That is, investing in health care appears to reduce the negative effect of ill-health on life satisfaction: becoming ill in a country with meager health care spending might result in accumulating personal debt or refusing medical treatment altogether, ultimately resulting in further health deterioration. 
The generosity of the welfare state was shown not only to compensate for individuals' health problems, but also to make life easier for the elderly. For example, Moor, de Graaf and Komter (2013) showed that older individuals are more satisfied with life in countries with better welfare services targeted at the elderly. Specifically, they detected a positive association between the share of the elderly in institutional care homes (used as an indicator of the welfare generosity directed at the elderly) and the life satisfaction of elderly individuals in general. Similarly, the negative consequences of financial hardship among the elderly are buffered by the generosity of the welfare state. Specifically, Niedzwiedz et al. (2015), using the data of elderly individuals (Survey of Health, Ageing, and Retirement in Europe) living in Southern, Scandinavian, Postcommunist, and Bismarckian welfare regimes, demonstrated that the negative effect on SWB exerted by low socioeconomic status was attenuated in Scandinavian regimes (which are known for their generous social spending).

\subsubsection{Migration}

In light of the ongoing migration and refugee crisis in the Europe, several studies examined the role of social policies in migrants' satisfaction (see also Careja 2019). Kogan et al. (2017) showed that the life satisfaction of immigrants in Europe (18 EU countries were analyzed) depends much more on natives' attitudes toward migration than it does on legal immigration regulations and policies. A welcoming social climate including positive migration attitudes was shown to make a happy migrant. Heizmann and Böhnke (2018) distinguished between migrants from the EU and other countries, and found that Kogan and colleagues' findings primarily apply to migrants from the EU, whereas the life satisfaction of migrants from outside the EU does benefit from inclusive integration policies.

\subsubsection{Gender}

Besides specific policies directed at improving the living conditions of one or another group, cross-national sociological research considered inequalities between different social groups. For example, Başlevent and Kirmanoğlu (2017) explored the happiness gap between working women and housewives across 29 European countries. They showed that working women were happier than housewives and that this happiness gap increased with increasing country-level gender equality in economic participation, educational attainment, and political empowerment. Crossnational differences in gender equality were also shown to explain between-country variation in gender differences in happiness, with women being more satisfied in more gender-equal countries (Tesch-Roemer et al. 2008). However, this finding was not replicated among adolescents. Looze et al. (2017) used individual-level data of over 150,000 adolescents from 34 European and North American countries. Their analyses indicated that the national-level of gender equality (e.g. women's economic participation and decision-making power in politics and business) showed a positive association with life satisfaction in both boys and girls to the same extent. Similarly, despite some support for a positive effect of gender equality on women's happiness, researchers have also noticed that the happiness of American women has been in 
decline since the 1970s, despite growing gender equality (Stevenson and Wolfers 2009). Potentially, increases in gender equality resulted in a higher role ambiguity and role conflict in women who are now supposed to succeed in both family life and at work (see also Grunow 2019). These findings point toward a limitation of the institutional approach, showing that an objective improvement in living conditions might do little to enhance happiness, unless it is followed by the requisite changes in the sociocultural climate.

\subsubsection{Miscellaneous}

Although most research testing the "institutional hypothesis" explored the role of social policies, institutional and structural differences can more generally foster or undermine the well-being of one or another group as well. For example, Tay et al. (2014), who analyzed individual-level data from over 100 countries, showed that the positive association between individuals' income and SWB is enhanced in countries with higher national corruption levels (probably as it allows one to bribe more officials - an ability crucial for survival in corrupt countries). Sortheix and Schwartz (2017) examined the effect of personal values from Schwartz's values theory on life satisfaction across 25 European countries and showed that while the effects of some values did not show meaningful cross-cultural variations (e.g. high benevolence and hedonism values were related to higher life satisfaction, whereas high power and security values were related to lower life satisfaction), the effects of other values were less universal ${ }^{1}$. For example, individuals scoring high on achievement value were more satisfied with life if they lived in countries with lower scores in the Human Development Index, whereas individuals scoring lower on achievement values were happier in countries with higher scores in the Human Development Index. A strong achievement orientation might potentially foster prosperity, which is more important for well-being in developing than in developed countries.

\subsection{The Fit Hypothesis}

The role of sociocultural climate has been the focus of psychological research exploring cross-cultural differences in correlates of SWB. This line of research advanced what can be called a "fit hypothesis", according to which individuals' characteristics contribute to SWB to the degree to which these characteristics are widespread and, consequently, socially desirable in a particular culture (Stavrova 2014; Stavrova et al. 2013a, b). This theoretical perspective is grounded in decades of psychological research on normative conformity, social sanctions, social identity and person-environment fit (Abrams et al. 2002; Cialdini and Goldstein 2004; Kristof-Brown et al. 2005).

Studies on the psychology of social processes showed that people like similar others more than dissimilar others (Byrne 1961) and judge members of their in-group more positively than members of their out-group (Tajfel et al. 1971). Similarly, peo-

\footnotetext{
1 Personal values represent individual characteristics (other than personality traits) that reflect individuals' guiding principles in life (Schwartz 1992).
} 
ple judge group members holding opinions or views that deviate from the group's average as socially unattractive and unlikeable; they are more likely to ostracize and exclude them from the group (Abrams et al. 2002; Ouwerkerk et al. 2005). This idea is supported by the studies on conformity and norm violations, showing that people whose behavior or opinions deviate from social norms are often subject to informal social sanctions, such as disapproval and exclusion (Christensen et al. 2004; Pool et al. 1998). In fact, as shown by the research on the backlash effect, behaviors typically related to social approval and respect might backfire and result in disrespect when executed by those for whom they represent a violation of social norms (Rudman and Fairchild 2004). For example, volubility, expressions of anger and assertive negotiation techniques have overwhelmingly positive consequences for men, but negative ones for women (Brescoll 2011; Brescoll and Uhlmann 2008). People are often aware of the backlash that being different than the majority can elicit. This is illustrated by the so called Spiral of Silence phenomenon that describes the hesitancy with which minority (vs. majority) opinion holders express their opinions (Noelle-Neumann 1974). For example, individuals who believe that their opinion is discrepant from (vs. congruent with) the majority's opinion are slower (that is, more hesitant) when it comes to publicly sharing their opinion (Bassili 2003).

Finally, studies in organizational psychology (Kristof-Brown et al. 2005) have demonstrated the importance of fit between individuals and their immediate work contexts. These studies have shown that individuals whose values, goals, and personality are similar to those in their organization or team are more likely to have higher job satisfaction, commitment and performance than individuals who are dissimilar to their immediate work environment (Kristof-Brown et al. 2005).

The idea of fit has transcended cross-cultural literature on correlates of SWB as well. Cross-cultural studies in psychology traditionally focus on comparing the predictive validity of the same characteristic across several countries with different scores in important cultural dimensions, such as individualism vs. collectivism. Individualistic cultures value positive emotions, autonomy and self-concern, whereas collectivistic cultures place emphasis on relationships concern, interdependence and normative conformity (Oyserman et al. 2002). Consistent with the fit perspective, relationship concern was shown to be a stronger predictor of SWB in collectivistic cultures, whereas self-concern was a stronger predictor of SWB in individualistic ones (Mesquita and Karasawa 2002). Similarly, satisfaction with one's freedom, experiences of positive emotions and valuing pleasure (hedonism) were more strongly associated with life satisfaction in individualistic countries than in collectivistic ones (Joshanloo and Jarden 2016; Oishi et al. 1999; Suh et al. 1998). Taken together, these findings suggest that people are happy and satisfied with life to the extent that their characteristics are in harmony with cultural values.

Although cultural differences along the individualism vs. collectivism dimension are well established, they might not represent the optimal way to explore the fit hypothesis. Individualism-collectivism (as well as any other cultural dimension) describes cultural differences not just in one but in multiple values, needs, traditions, customs and the like, and thus lack the specificity required for a straightforward test of the fit idea. 
A most recent stream of research therefore explored the fit hypothesis more directly by investigating the interactions between individuals' characteristics and the degree to which these characteristics are widespread and socially desirable in a given cultural context. These two aspects of normative behaviors-being common and socially desirable - represent core attributes of social norms in social psychological literature (Cialdini et al. 1990). They are referred to as descriptive (as they describe behaviors that people commonly exercise under certain circumstances) and injunctive (as they describe behaviors that people believe one should exercise under certain circumstances). It should be noted that this approach differs from the dominant view in the sociological literature that only recognizes the injunctive (but not the descriptive) component as part of the definition of social norms (Coleman 1990). Using the social norms approach to explain cross-national differences produced promising results by demonstrating the importance of fit for SWB in different life domains. For example, the happiness gap between employed and unemployed individuals was shown to vary as a function of a country-level social norm to work, with the unemployed being especially dissatisfied with their lives in countries with a strong social work ethic (Stavrova et al. 2011).

The person-culture fit pattern also emerged with respect to other areas of human life, such as marital status and parenthood. For example, while cohabiting women are often shown to report lower SWB than their married counterparts, this effect was shown to be restricted to countries with a strong norm for women to get married (Stavrova et al. 2012). Similarly, the misery of single parents and parents raising a child out of wedlock (cohabiting) could be substantially alleviated in cultural contexts with tolerant norms regarding childbearing practices. In countries where childbearing in cohabiting unions and by single parents is common and normatively accepted, there was a smaller gap in life satisfaction between married and cohabiting or single parents than in countries where these alternative family models were not accepted (Stavrova and Fetchenhauer 2015a, 2015b).

Interestingly, support for the fit hypothesis was also demonstrated with respect to less visible individual characteristics such as beliefs, worldviews, and ideologies. A series of studies showed that the positive effect of religious beliefs on SWB was restricted to religious countries (Gebauer et al. 2017; Stavrova et al. 2013). Similarly, holding specific secular beliefs, such as a belief in scientific-technological progress, was associated with a higher SWB to the extent that this belief was common in a particular cultural context (Stavrova et al. 2016). Conservative political ideology was a positive predictor of SWB only in above-average conservative contexts (Stavrova and Luhmann 2016a). Finally, even the effect of characteristics that are sometimes described as representing universal sources of happiness, such as virtue and prosociality (Aknin et al. 2013) has been shown to vary across countries, following a fit pattern. For example, helping others was related to higher life satisfaction in countries where helping was common than in countries where helping others was rare (Oarga et al. 2015). Similarly, the positive effect of civic virtue on life satisfaction turned negative in countries where above-average virtuous behaviors in economic games was subject to sanctions (Stavrova et al. 2013b).

What mechanisms account for the fit effect? On the one hand, individuals who deviate from the majority behavior (or in other words who violate social norms) are 
likely to be sanctioned by their fellow group members. Indeed, multiple studies in social psychology and sociology have shown that individuals expressing a deviant opinion are more likely to be disliked by others and even ostracized (Christensen et al. 2004; Wood et al. 1997). In turn, social exclusion represents one of the most important factors that negatively affect psychological functioning (Williams 2007; Williams et al. 2000). Similarly, loneliness has been shown to hinder psychological well-being, resulting in poor health and even increased mortality risks (Cacioppo and Cacioppo 2014; Cacioppo et al. 2010). It follows that pursuing a lifestyle that significantly deviates from the social norms in one's surroundings is likely to give rise to negative behaviors from others, resulting in social isolation and therefore damaging one's sense of well-being. In brief, this explanation assumes that the reason behind the unhappiness of norm-deviant individuals are social sanctions- the toll of disrespect and the pain of social exclusion.

At the same time, social norms work not only because people fear punishment (social sanctions) in case of noncompliance, but also because they are often internalized and become part of individuals' selves. In this case, a lower SWB of normdeviant individuals might be explained by their self-disappointment and a feeling of guilt associated with failing to live up to one's own standards. Psychological studies have shown that people tend to make an effort to minimize the discrepancy between their actual and ideal self-concept (Crocker and Knight 2005). This mechanism is most likely to be at work in the case of involuntary nonconformity, such as involuntary unemployment (in a country with a strong work ethic), cohabitation (in a country with strong traditional family norms) or single parenthood (in a country with a strong two-parent family norm). Yet, nonconformity is sometimes more voluntary: People usually have some degree of freedom to decide whether they want to support a minority political ideology or become an atheist in a religious country. The negative consequences of nonconformity are therefore hard to explain in such cases by individuals' self-disappointment or guilt associated with falling short of reaching their ideal selves. After all, they could become their ideal selves if they just changed their views.

Several papers have attempted to explore which of the two mechanisms discussed above-deviance from social vs. personal norms - can best explain the negative effect of a lack of fit. In a cross-cultural study of unemployed individuals' well-being, Stavrova et al. (2011) included a measure of the norm to work at both individual and national level (the latter was obtained by aggregating individuals' responses to the norm to work scale). If individuals' deviation from their personal norm of work and the resulting feeling of self-discrepancy and guilt represent the underlying mechanisms of the fit effect, then the interaction between individuals' employment status and the national norm to work should vanish once researchers control for individual differences in the personal norm to work. Yet this did not take place: the stronger the country-level norm to work was, the less happy the unemployed were, regardless of how strong or weak their personal norm to work was. Similar results were obtained in a couple of other studies that explored the role of social vs. personal norms. For example, in a study of 43 European countries, Stavrova and Fetchenhauer (2015b) showed that single parents were particularly dissatisfied with life in countries with a strong two-parent family norm. Importantly, this effect was 
present even among single parents who themselves did not hold a two-parent family norm, pointing to the working of the social sanction mechanism of the fit effect. The same conclusions were reached in a study of cohabiting parents' happiness: cohabiting (vs. married) parents were less happy in countries with strong traditional family norms, regardless of whether they themselves supported these norms or not (Stavrova and Fetchenhauer 2015a). Taken together, these findings provide support for the social sanctions (rather than norm internalization) explanation of the fit effect.

To summarize, the literature reviewed points to substantial cross-cultural variability in the degree to which individuals' characteristics are associated with SWB and thus challenges the assumption of the universality of human happiness. Existing literature seems to converge on the idea that multiple individuals' characteristics contribute to happiness to the extent that they are common and socially desirable in a particular sociocultural context. The cross-national variability in effect sizes can be considered as not only statistically but also practically significant. In fact, in some domains, the particularities of a national context do not only make an individual-level association smaller, but actually make it vanish or even reverse. Knowing what country-level characteristics switch the predictors of SWB on and off and why represents an important step in assessing the cross-national generalizability of SWB findings.

\section{Directions for Future Research}

Although cross-national comparative research on SWB has been greatly facilitated by the inclusion of measures of life satisfaction in most cross-national large-scale survey programs, it is still in its infancy. The vast majority of cross-cultural studies in psychology still involve comparing findings across two or three countries or cultural contexts. While this approach usually uses highly valid instruments and sophisticated (experimental or longitudinal) study designs, it does not permit any definitive conclusions to be drawn about the role of country-level characteristics in explaining between-country differences in the results. To give an example, observing a positive association between self-esteem and happiness in individualistic Canada and a zero correlation in collectivistic Japan is informative, yet it tells us little about the role of individualism in driving these differences.

In this sense, studies that rely on large-scale cross-national survey datasets and statistically test the effect of contextual characteristics on within-country relationships (e.g. using a multilevel analysis) represent an important methodological advancement. The availability of basic SWB measures in multiple large-scale crossnational studies currently allows researchers to explore the variations in correlates of life satisfaction across more than 100 countries. Yet, this research is restricted by the measures available in such datasets. While personality characteristics (e.g. the Big Five personality traits) represent the most important predictors of SWB, there is currently not a single publicly available cross-national dataset that includes reliable measures of personality. On the contrary, such datasets usually include measures of sociodemographic characteristics, values, attitudes, and behaviors-aspects that were shown to explain relatively little variance in SWB (Lyubomirsky et al. 
2005 b). As a result, we know quite a lot about the cross-cultural variability of factors whose overall impact on SWB is small, but we know very little about the crosscultural variability of the most important predictors of SWB, such as personality. As SWB is not only a topic of interest to psychologists, but also to sociologists and economists, it is highly recommended for cross-national large-scale survey projects to include measures of basic dimensions of personality to fill in this knowledge and data infrastructure gap.

Another limitation that is associated with the nature of available cross-national data is that such data are usually cross-sectional and, thus, do not allow causal inferences. Nevertheless, most studies using cross-national data tend to interpret their results in causal terms, typically implying a causal effect of individuals' characteristics on their happiness (see also Schmidt-Catran et al. 2019). Indeed, most theoretical models in sociology and economics consider happiness as an outcome, not as a predictor. However, recent longitudinal studies have shown that individual differences that usually serve to predict SWB might well be its outcomes. These studies have shown that life satisfaction and happiness contribute to better health and longevity (Danner et al. 2001; Diener and Chan 2011; Stavrova 2019), as well as career success (Cropanzano and Wright 1999; Rose and Stavrova 2019), and can even trigger important life events such as marriage or separation (Luhmann et al. 2013; Stavrova and Luhmann 2016b). These findings make the interpretation of established patterns of cross-cultural variations in correlates of SWB problematic. For example, the fit perspective assumes that endorsing culturally shared beliefs contributes to SWB. Alternatively, it is plausible that (1) SWB contributes to the endorsement of culturally shared beliefs or (2) that both SWB and the endorsement of culturally shared beliefs are driven by further unassessed factors (e. g. high selfcontrol might result in both higher SWB and conformity). It is possible that not only the strength but also the causal direction of the associations between individual characteristics and SWB varies across countries. To conclude, extending cross-national studies on correlates of SWB to include longitudinal or experimental (when appropriate) data in select countries will become crucial in advancing this research field.

While most empirical work exploring cross-national variability in correlates of SWB falls under one of the two theoretical approaches described here-institutional and fit hypotheses - there are multiple further macro-level indicators reflecting different aspects of individuals' living conditions (wealth, social inequality, political freedom, etc.) that can be used to explain cross-national differences in the correlates of SWB. The most prominent example is the role of national wealth (GDP per capita) in the association between individuals' income and their SWB. A couple of studies have shown that the positive association between individuals' income and their SWB is stronger in poorer countries than in wealthier ones (Diener et al. 2010; Schyns 2002), suggesting that money buys happiness when it ensures that basic needs are met (access to clean water, medical care, etc.). An exploration of how country-level differences in further objectively measurable characteristics such as income inequality, human development or particularities of the political regime might be a worthwhile endeavor for future cross-national comparative research. 
It should be acknowledged that cross-national comparative research on hedonic components of well-being has been flourishing despite these limitations. In contrast, however, cross-cultural studies on eudaimonic well-being are virtually nonexistent. Yet, eudaimonic well-being-in particular its currently most often studied component, meaning in life-is of increasing importance for both individuals and society to function (Hill and Turiano 2014; Stavrova and Luhmann 2016b). In fact, monitoring and seeking to improve citizens' sense of meaning in life has been discussed as a potential matter of public policy (Steger 2014). Hence, exploring cross-cultural differences in mean levels and correlates of meaning in life might represent an important direction for future studies.

On a related note, the theoretical developments in the area of cross-national SWB research might be used to explain cross-national differences in predictors of physical health. Indeed, a series of recent studies have detected that cross-national variations in the associations between religiosity and physical health show a fit pattern as well. Across nearly 60 countries, religious individuals only enjoyed better physical health than nonreligious individuals in countries where religiosity was common and socially desirable. In contrast, in secular countries, being religious was not associated with any physical health advantage. This pattern was detected across the U.S. census regions and was even extended to mortality risks. Religiosity was only related to lower mortality risks in highly religious regions (e.g. the Bible Belt; Stavrova 2015b).

It is noteworthy that certain statistical techniques, such as multilevel regression or multilevel structural equation modeling, made testing both the institutional and the fit hypotheses possible. Nevertheless, a substantial number of countries is typically required for this technique to lead to reliable conclusions, and most of the studies reviewed here barely satisfied these requirements (Hox 2002). Besides including more countries, one way to address this limitation is to move to a lower level of analysis (e.g. studying regions within one or several countries). Adopting this method might be particularly promising when trying to disentangle the institutional and the fit hypotheses: while institutional effects most often exist at national level, the effect of social norms and culture can be tested at lower levels as well.

Finally, understanding what drives cross-cultural differences in correlates of SWB might represent a tool for studying the mechanisms behind the associations between individual characteristics and happiness. For example, research on the positive effect of religiosity on life satisfaction has considered multiple potential mechanisms, including increased social networks (Lim and Putnam 2009), healthy behaviors (Wallace and Forman 1998), as well as social approval and respect (Gebauer et al. 2017), etc. The fact that the positive effect of religiosity is restricted to religious countries can be interpreted as providing support to the social approval mechanism. In other words, religiosity is only related to increased life satisfaction in contexts where it represents a source of higher social esteem, approval and recognition, suggesting that it is these social benefits (rather than healthy behaviors or other factors) that represent the underlying mechanism of the effect. 


\section{Conclusions}

Why study happiness? Besides feeling good, happiness is associated with many positive life outcomes. Happy people benefit from better health and longevity (Danner et al. 2001), career success (Cropanzano and Wright 1999), and positive relationships (Stavrova and Luhmann 2016b) than their less happy counterparts (for a review, see Lyubomirsky et al. 2005a). Happiness promotes helping and prosociality (Dulin and Hill 2003), broadens individuals' cognitive repertoire (Fredrickson and Branigan 2005) and involvement with approach goals (Elliot and Thrash 2002). Hence, the study of happiness and factors promoting individuals' happiness appears an important endeavor with the potential to improve the human condition.

Cross-national comparative research on SWB has enjoyed fast-growing interest from a number of social science disciplines. These studies made substantial contributions to our understanding of cultural differences in mean levels and correlates of SWB. Further extending empirical studies to include longitudinal and experimental designs and promoting theory building in the area might represent the most immediate steps that future research should undertake.

Open Access This article is distributed under the terms of the Creative Commons Attribution 4.0 International License (http://creativecommons.org/licenses/by/4.0/), which permits unrestricted use, distribution, and reproduction in any medium, provided you give appropriate credit to the original author(s) and the source, provide a link to the Creative Commons license, and indicate if changes were made.

\section{Appendix}

Table 1 Overview of the empirical papers. Author's own work

\begin{tabular}{|c|c|c|c|c|}
\hline Paper & $\begin{array}{l}\text { Individual-level } \\
\text { variables }\end{array}$ & $\begin{array}{l}\text { Country-level } \\
\text { variables }\end{array}$ & $\begin{array}{l}\text { Num- } \\
\text { ber of } \\
\text { coun- } \\
\text { tries }\end{array}$ & Main finding \\
\hline $\begin{array}{l}\text { Voßemer } \\
\text { et al. (2017) }\end{array}$ & $\begin{array}{l}\text { Unemployment; } \\
\text { insecure employ- } \\
\text { ment }\end{array}$ & $\begin{array}{l}\text { Passive and } \\
\text { active labor } \\
\text { market policies; } \\
\text { employment } \\
\text { protection legis- } \\
\text { lation }\end{array}$ & 26 & $\begin{array}{l}\text { Higher unemployment benefits } \\
\text { are related to a weaker negative } \\
\text { effect of unemployment on SWB. } \\
\text { Higher active labor market poli- } \\
\text { cies expenditures are associated } \\
\text { with stronger negative effects of } \\
\text { unemployment on SWB }\end{array}$ \\
\hline $\begin{array}{l}\text { Ochsen } \\
\text { and Welsch } \\
(2012)\end{array}$ & $\begin{array}{l}\text { Employment }+ \\
\text { sociodemographics }\end{array}$ & $\begin{array}{l}\text { Employment } \\
\text { protection and } \\
\text { unemployment } \\
\text { benefits policies }\end{array}$ & 10 & $\begin{array}{l}\text { The positive effect of employment } \\
\text { protection on SWB is stronger } \\
\text { in employed persons of interme- } \\
\text { diate age (compared to women/ } \\
\text { housewives and older people). The } \\
\text { effect of generous unemployment } \\
\text { insurance on SWB is stronger in } \\
\text { women/housewives, older people } \\
\text { and the unemployed }\end{array}$ \\
\hline
\end{tabular}


Table 1 (Continued)

\begin{tabular}{|c|c|c|c|c|}
\hline Paper & $\begin{array}{l}\text { Individual-level } \\
\text { variables }\end{array}$ & $\begin{array}{l}\text { Country-level } \\
\text { variables }\end{array}$ & $\begin{array}{l}\text { Num- } \\
\text { ber of } \\
\text { coun- } \\
\text { tries }\end{array}$ & Main finding \\
\hline $\begin{array}{l}\text { Eichhorn } \\
\text { (2014) }\end{array}$ & Unemployment & $\begin{array}{l}\text { Unemployment } \\
\text { benefits; inflation } \\
\text { rate; country- } \\
\text { level share of the } \\
\text { elderly }\end{array}$ & 28 & $\begin{array}{l}\text { The effect of unemployment on } \\
\text { life satisfaction is not moderated } \\
\text { by unemployment benefits. Higher } \\
\text { inflation rates and higher propor- } \\
\text { tions of the elderly in the popula- } \\
\text { tion are associated with a stronger } \\
\text { negative effect of unemployment } \\
\text { on SWB }\end{array}$ \\
\hline $\begin{array}{l}\text { Annink et al. } \\
(2016)\end{array}$ & $\begin{array}{l}\text { Financial hard- } \\
\text { ship in self- } \\
\text { employed indi- } \\
\text { viduals }\end{array}$ & $\begin{array}{l}\text { Unemployment } \\
\text { benefits policies }\end{array}$ & 31 & $\begin{array}{l}\text { Financial hardship has a weaker } \\
\text { effect on the SWB of self-em- } \\
\text { ployed individuals in countries } \\
\text { with the presence of unemploy- } \\
\text { ment benefits policy }\end{array}$ \\
\hline $\begin{array}{l}\text { Glass et al. } \\
(2016)\end{array}$ & Parenthood & $\begin{array}{l}\text { Policies allowing } \\
\text { paid time off } \\
\text { and childcare } \\
\text { subsidies }\end{array}$ & 22 & $\begin{array}{l}\text { The negative effect of parenthood } \\
\text { on SWB is weaker in countries } \\
\text { with more general policies im- } \\
\text { plementing paid time off and } \\
\text { childcare subsidies }\end{array}$ \\
\hline $\begin{array}{l}\text { Neuberger } \\
\text { and Preisner } \\
(2017)\end{array}$ & $\begin{array}{l}\text { Parenthood in } \\
\text { old age }\end{array}$ & $\begin{array}{l}\text { Gross domestic } \\
\text { product; social } \\
\text { service expendi- } \\
\text { tures }\end{array}$ & 19 & $\begin{array}{l}\text { The positive effect of parent- } \\
\text { hood is stronger in countries with } \\
\text { lower Gross Domestic Product and } \\
\text { higher social service spending }\end{array}$ \\
\hline $\begin{array}{l}\text { Kööts- } \\
\text { Ausmees } \\
\text { and Realo } \\
(2015)\end{array}$ & Subjective health & $\begin{array}{l}\text { Health care } \\
\text { spending }\end{array}$ & 32 & $\begin{array}{l}\text { The positive association between } \\
\text { subjective health and SWB is } \\
\text { stronger in countries with lower } \\
\text { government spending on health } \\
\text { care programs }\end{array}$ \\
\hline $\begin{array}{l}\text { Niedzwiedz } \\
\text { et al. (2015) }\end{array}$ & $\begin{array}{l}\text { Life course so- } \\
\text { cio-economic } \\
\text { index }\end{array}$ & $\begin{array}{l}\text { Welfare state } \\
\text { regimes }\end{array}$ & 13 & $\begin{array}{l}\text { The negative effect of a low so- } \\
\text { cioeconomic index on SWB is } \\
\text { attenuated in Scandinavian welfare } \\
\text { state regimes }\end{array}$ \\
\hline $\begin{array}{l}\text { Moor et al. } \\
(2013)\end{array}$ & Old age & $\begin{array}{l}\text { Welfare state } \\
\text { services targeted } \\
\text { at the elderly }\end{array}$ & 47 & $\begin{array}{l}\text { Older people living in countries } \\
\text { with a higher (vs. lower) share of } \\
\text { older adults in institutional care } \\
\text { facilities report higher SWB. The } \\
\text { replacement rates for pensions } \\
\text { were not related to the elderly's } \\
\text { SWB }\end{array}$ \\
\hline $\begin{array}{l}\text { Kogan et al. } \\
(2017)\end{array}$ & Migration status & $\begin{array}{l}\text { Natives' attitudes } \\
\text { toward immi- } \\
\text { grants; immi- } \\
\text { gration policies } \\
\text { (Migration In- } \\
\text { tegration Policy } \\
\text { Index) }\end{array}$ & 18 & $\begin{array}{l}\text { Positive natives' attitudes towards } \\
\text { immigrants have a positive rela- } \\
\text { tionship with immigrants' SWB, } \\
\text { while immigration regulations and } \\
\text { policies are unrelated to immi- } \\
\text { grants' SWB }\end{array}$ \\
\hline
\end{tabular}


Table 1 (Continued)

\begin{tabular}{|c|c|c|c|c|}
\hline Paper & $\begin{array}{l}\text { Individual-level } \\
\text { variables }\end{array}$ & $\begin{array}{l}\text { Country-level } \\
\text { variables }\end{array}$ & $\begin{array}{l}\text { Num- } \\
\text { ber of } \\
\text { coun- } \\
\text { tries }\end{array}$ & Main finding \\
\hline $\begin{array}{l}\text { Heizmann } \\
\text { and Böhnke } \\
(2018)\end{array}$ & $\begin{array}{l}\text { Migration status: } \\
\text { national citizens, } \\
\text { EU citizens and } \\
\text { third-country } \\
\text { nationals }\end{array}$ & $\begin{array}{l}\text { Natives' attitudes } \\
\text { toward immi- } \\
\text { grants; immi- } \\
\text { gration policies } \\
\text { (Migration In- } \\
\text { tegration Policy } \\
\text { Index) }\end{array}$ & 25 & $\begin{array}{l}\text { The SWB of third-country nation- } \\
\text { als is most strongly (positively) } \\
\text { affected by migrant-friendly pol- } \\
\text { icy-making, whereas the SWB of } \\
\text { EU migrants is mostly affected by } \\
\text { positive natives' attitudes toward } \\
\text { immigrants }\end{array}$ \\
\hline $\begin{array}{l}\text { Başlevent } \\
\text { and Kir- } \\
\text { manoğlu } \\
(2017)\end{array}$ & $\begin{array}{l}\text { Working women } \\
\text { vs. housewives }\end{array}$ & $\begin{array}{l}\text { Gender inequal- } \\
\text { ity index }\end{array}$ & 29 & $\begin{array}{l}\text { Working women report higher } \\
\text { SWB than housewives, especially } \\
\text { in countries with greater gender } \\
\text { equality }\end{array}$ \\
\hline $\begin{array}{l}\text { Tesch- } \\
\text { Roemer } \\
\text { et al. (2008) }\end{array}$ & Gender & $\begin{array}{l}\text { Gender inequal- } \\
\text { ity index }\end{array}$ & 57 & $\begin{array}{l}\text { Women are more satisfied in more } \\
\text { gender egalitarian countries }\end{array}$ \\
\hline $\begin{array}{l}\text { Looze et al. } \\
(2017)\end{array}$ & $\begin{array}{l}\text { Gender (among } \\
\text { adolescents) }\end{array}$ & $\begin{array}{l}\text { Gender inequal- } \\
\text { ity index }\end{array}$ & 34 & $\begin{array}{l}\text { The gender inequality index is } \\
\text { equally associated with life sat- } \\
\text { isfaction among both boys and } \\
\text { girls (their SWB is higher in more } \\
\text { gender-equal countries) }\end{array}$ \\
\hline $\begin{array}{l}\text { Tay et al. } \\
(2014)\end{array}$ & $\begin{array}{l}\text { Household in- } \\
\text { come }\end{array}$ & $\begin{array}{l}\text { National corrup- } \\
\text { tion level }\end{array}$ & 150 & $\begin{array}{l}\text { The positive association between } \\
\text { individuals' income and SWB is } \\
\text { enhanced in countries with higher } \\
\text { national corruption levels }\end{array}$ \\
\hline $\begin{array}{l}\text { Sortheix and } \\
\text { Schwartz } \\
(2017)\end{array}$ & Personal values & $\begin{array}{l}\text { Cultural egal- } \\
\text { itarianism in- } \\
\text { dex (based on } \\
\text { Schwartz cultural } \\
\text { values); Human } \\
\text { Development } \\
\text { Index }\end{array}$ & $32 / 25$ & $\begin{array}{l}\text { In countries with a lower (vs. } \\
\text { higher) Cultural Egalitarianism } \\
\text { index, SWB is associated more } \\
\text { positively with openness, more } \\
\text { negatively with conservation, less } \\
\text { negatively with self-enhance- } \\
\text { ment, and less positively with self- } \\
\text { transcendence values. A similar } \\
\text { pattern emerged for Human Devel- } \\
\text { opment Index }\end{array}$ \\
\hline $\begin{array}{l}\text { Oishi et al. } \\
\text { (1999) }\end{array}$ & $\begin{array}{l}\text { Financial satis- } \\
\text { faction; esteem } \\
\text { needs? }\end{array}$ & $\begin{array}{l}\text { Individualism; } \\
\text { GDP }\end{array}$ & 39 & $\begin{array}{l}\text { The positive association between } \\
\text { financial satisfaction and SWB is } \\
\text { stronger in poorer (vs. wealthier) } \\
\text { nations. The positive association } \\
\text { between the satisfaction of esteem } \\
\text { needs and SWB is stronger in } \\
\text { individualistic (vs. collectivistic) } \\
\text { nations }\end{array}$ \\
\hline $\begin{array}{l}\text { Suh et al. } \\
(1998)\end{array}$ & Emotions & Individualism & 61 & $\begin{array}{l}\text { Emotions are a stronger predictor } \\
\text { of SWB in individualistic (vs. } \\
\text { collectivistic) countries }\end{array}$ \\
\hline
\end{tabular}


Table 1 (Continued)

\begin{tabular}{|c|c|c|c|c|}
\hline Paper & $\begin{array}{l}\text { Individual-level } \\
\text { variables }\end{array}$ & $\begin{array}{l}\text { Country-level } \\
\text { variables }\end{array}$ & $\begin{array}{l}\text { Num- } \\
\text { ber of } \\
\text { coun- } \\
\text { tries }\end{array}$ & Main finding \\
\hline $\begin{array}{l}\text { Joshanloo } \\
\text { and Jarden } \\
(2016)\end{array}$ & Hedonism values & Individualism & 19 & $\begin{array}{l}\text { Hedonism values are more } \\
\text { strongly (positively) associated } \\
\text { with SWB in individualistic (vs. } \\
\text { collectivistic) countries }\end{array}$ \\
\hline $\begin{array}{l}\text { Stavrova } \\
\text { et al. (2011) }\end{array}$ & $\begin{array}{l}\text { Unemployment } \\
\text { status }\end{array}$ & $\begin{array}{l}\text { Social work } \\
\text { ethic; national } \\
\text { unemployment } \\
\text { rates }\end{array}$ & 28 & $\begin{array}{l}\text { The negative effect of unemploy- } \\
\text { ment on SWB was alleviated in } \\
\text { counties with a weak social work } \\
\text { ethic; national unemployment } \\
\text { rates did not moderate the effect of } \\
\text { unemployment on SWB }\end{array}$ \\
\hline $\begin{array}{l}\text { Stavrova } \\
\text { et al. (2012) }\end{array}$ & $\begin{array}{l}\text { Gender and part- } \\
\text { nership arrange- } \\
\text { ment (marriage } \\
\text { vs. cohabitation) }\end{array}$ & $\begin{array}{l}\text { Gender role } \\
\text { norms }\end{array}$ & 30 & $\begin{array}{l}\text { Cohabiting women report lower } \\
\text { SWB than married women do, } \\
\text { especially in countries with con- } \\
\text { servative gender role norms; gen- } \\
\text { der role norms had no effect on } \\
\text { cohabiting vs. married men's SWB }\end{array}$ \\
\hline $\begin{array}{l}\text { Stavrova } \\
\text { et al. } \\
(2013 a)\end{array}$ & $\begin{array}{l}\text { Personal religios- } \\
\text { ity }\end{array}$ & $\begin{array}{l}\text { Social norm of } \\
\text { religiosity }\end{array}$ & 64 & $\begin{array}{l}\text { Religiosity is positively associated } \\
\text { with SWB, and this relationship is } \\
\text { especially strong in countries with } \\
\text { a stronger (vs. weaker) norm of } \\
\text { religiosity }\end{array}$ \\
\hline $\begin{array}{l}\text { Stavrova } \\
\text { et al. } \\
(2013 b)\end{array}$ & Civic virtue & $\begin{array}{l}\text { Country-level } \\
\text { civic virtue; } \\
\text { country-level } \\
\text { antisocial pun- } \\
\text { ishment (pun- } \\
\text { ishment of high } \\
\text { contributors in } \\
\text { public goods } \\
\text { games) rates }\end{array}$ & $73 / 13$ & $\begin{array}{l}\text { Civic virtue is positively asso- } \\
\text { ciated with SWB, but less so in } \\
\text { countries with a weak country- } \\
\text { level civic virtue and high country- } \\
\text { level antisocial punishment rates }\end{array}$ \\
\hline $\begin{array}{l}\text { Oarga et al. } \\
(2015)\end{array}$ & $\begin{array}{l}\text { Prosocial behav- } \\
\text { ior }\end{array}$ & $\begin{array}{l}\text { Country-level } \\
\text { norm of proso- } \\
\text { ciality }\end{array}$ & 23 & $\begin{array}{l}\text { Prosocial behavior is positively } \\
\text { related to SWB, especially in } \\
\text { countries with a strong norm of } \\
\text { prosociality }\end{array}$ \\
\hline $\begin{array}{l}\text { Stavrova and } \\
\text { Fetchen- } \\
\text { hauer } \\
(2015 \mathrm{~b})\end{array}$ & $\begin{array}{l}\text { Marital status } \\
\text { and parenthood }\end{array}$ & $\begin{array}{l}\text { Country-level } \\
\text { two-parent } \\
\text { family norms; } \\
\text { individualism }\end{array}$ & 43 & $\begin{array}{l}\text { Parenthood more negatively af- } \\
\text { fects the SWB of single than of } \\
\text { partnered individuals, especially } \\
\text { in collectivistic countries and } \\
\text { counties with a strong two-parent } \\
\text { family norm }\end{array}$ \\
\hline $\begin{array}{l}\text { Stavrova and } \\
\text { Fetchen- } \\
\text { hauer } \\
(2015 a)\end{array}$ & $\begin{array}{l}\text { Marital status } \\
\text { and parenthood }\end{array}$ & $\begin{array}{l}\text { Country-level } \\
\text { childbearing } \\
\text { norms }\end{array}$ & 24 & $\begin{array}{l}\text { Cohabiting parents report lower } \\
\text { SWB than married parents do, but } \\
\text { only in countries with a strong } \\
\text { norm proscribing childbearing in } \\
\text { cohabiting unions }\end{array}$ \\
\hline
\end{tabular}


Table 1 (Continued)

\begin{tabular}{|c|c|c|c|c|}
\hline Paper & $\begin{array}{l}\text { Individual-level } \\
\text { variables }\end{array}$ & $\begin{array}{l}\text { Country-level } \\
\text { variables }\end{array}$ & $\begin{array}{l}\text { Num- } \\
\text { ber of } \\
\text { coun- } \\
\text { tries }\end{array}$ & Main finding \\
\hline $\begin{array}{l}\text { Stavrova } \\
\text { et al. }(2016)\end{array}$ & $\begin{array}{l}\text { Belief in scien- } \\
\text { tific-technologi- } \\
\text { cal progress }\end{array}$ & $\begin{array}{l}\text { Country-level be- } \\
\text { lief in scientific- } \\
\text { technological } \\
\text { progress }\end{array}$ & 72 & $\begin{array}{l}\text { The positive association between } \\
\text { belief in scientific-technological } \\
\text { progress and SWB is stronger } \\
\text { in countries with a stronger (vs. } \\
\text { weaker) average belief in scien- } \\
\text { tific-technological progress }\end{array}$ \\
\hline $\begin{array}{l}\text { Stavrova and } \\
\text { Luhmann } \\
(2016 a)\end{array}$ & $\begin{array}{l}\text { Political ideol- } \\
\text { ogy }\end{array}$ & $\begin{array}{l}\text { Country-level } \\
\text { political ideology }\end{array}$ & 92 & $\begin{array}{l}\text { Political conservatism is positively } \\
\text { associated with SWB, especially } \\
\text { in countries with stronger average } \\
\text { political conservatism }\end{array}$ \\
\hline $\begin{array}{l}\text { Roex and } \\
\text { Rözer } \\
(2018)\end{array}$ & $\begin{array}{l}\text { Unemployment } \\
\text { status }\end{array}$ & $\begin{array}{l}\text { Country-level } \\
\text { social work ethic }\end{array}$ & 31 & $\begin{array}{l}\text { The negative effect of unemploy- } \\
\text { ment on SWB is stronger in coun- } \\
\text { tries with a strong work ethic } \\
\text { (especially for men and the long- } \\
\text { term unemployed) }\end{array}$ \\
\hline $\begin{array}{l}\text { Van de Velde } \\
\text { et al. (2017) }\end{array}$ & $\begin{array}{l}\text { Religious service } \\
\text { attendance; } \\
\text { frequency of } \\
\text { prayer }\end{array}$ & $\begin{array}{l}\text { Country-level } \\
\text { religiosity }\end{array}$ & 29 & $\begin{array}{l}\text { The negative association between } \\
\text { service attendance and depres- } \\
\text { sion is weaker in less (vs. more) } \\
\text { religious countries. The positive } \\
\text { association between frequency of } \\
\text { prayer and depression is stronger } \\
\text { in less (vs. more) religious coun- } \\
\text { tries }\end{array}$ \\
\hline
\end{tabular}

\section{References}

Abrams, Dominic, José Marques, Nicola Bown, and Melanie Dougill. 2002. Anti-norm and pro-norm deviance in the bank and on the campus: two experiments on subjective group dynamics. Group Processes \& Intergroup Relations 5:163-182.

Aknin, Lara B., Christopher P. Barrington-Leigh, Elizabeth W. Dunn, John F. Helliwell, Justine Burns, Robert Biswas-Diener, Imelda Kemeza, Paul Claire E.Ashton-James Nyende, and Michael I. Norton. 2013. Prosocial spending and well-being: cross-cultural evidence for a psychological universal. Journal of Personality and Social Psychology 104:635-652.

Annink, Anne, Marjan Gorgievski, and Laura Den Dulk. 2016. Financial hardship and well-being: a crossnational comparison among the European self-employed. European Journal of Work and Organizational Psychology 25:645-657.

Balatsky, Galina, and Ed Diener. 1993. Subjective well-being among Russian students. Social Indicators Research 28:225-243.

Bassili, John N. 2003. The minority slowness effect: Subtle inhibitions in the expression of views not shared by others. Journal of Personality and Social Psychology 84:261-276.

Baumeister, Roy F., and Mark R. Leary. 1995. The need to belong: desire for interpersonal attachments as a fundamental human motivation. Psychological Bulletin 117:497-529.

Başlevent, Cem, and Hasan Kirmanoğlu. 2017. Gender inequality in Europe and the life satisfaction of working and non-working women. Journal of Happiness Studies 18:107-124.

Berger, Peter L., and Thomas Luckman. 1966. The social construction of reality: a treatise in the sociology of knowledge. Garden City: Doubleday.

Bonini, Astra. 2008. Cross-national variation in individual life satisfaction: effects of national wealth, human development, and environmental conditions. Social Indicators Research 87:223-236.

Bradburn, Norman M. 1969. The structure of psychological well-being. Chicago: Aldine.

Brescoll, Victoria L. 2011. Who takes the floor and why. Administrative Science Quarterly 56:622-641. 
Brescoll, Victoria L., and Eric Luis Uhlmann. 2008. Can an angry woman get ahead? Status conferral, gender, and expression of emotion in the workplace. Psychological Science 19:268-275.

Brief, Arthur P., Ann H. Butcher, Jennifer M. George and Karen E. Link. 1993. Integrating bottom-up and top-down theories of subjective well-being: the case of health. Journal of Personality and Social Psychology 64:646-653.

Byrne, Donn. 1961. Interpersonal attraction and attitude similarity. The Journal of Abnormal and Social Psychology 62:713-715.

Cacioppo, John T., and Stephanie Cacioppo. 2014. Social relationships and health: the toxic effects of perceived social isolation. Social and Personality Psychology Compass 8:58-72.

Cacioppo, John T., Louise C. Hawkley, and Ronald A. Thisted. 2010. Perceived social isolation makes me sad: 5-year cross-lagged analyses of loneliness and depressive symptomatology in the Chicago health, aging, and social relations study. Psychology and Aging 25:453-463.

Careja, Romana. 2019. Immigrants' labor market outcomes: Contributions from multilevel studies. In Cross-national comparative research - analytical strategies, results and explanations. Sonderheft Kölner Zeitschrift für Soziologie und Sozialpsychologie. Eds. Hans-Jürgen Andreß, Detlef Fetchenhauer and Heiner Meulemann. Wiesbaden: Springer VS. https://doi.org/10.1007/s11577-019-005978.

Carroll, Nick. 2007. Unemployment and psychological well-being. Economic Record 83:287-302.

Caspi, Avshalom, Daryl J. Bem and Glen H. Elder. 1989. Continuities and consequences of interactional styles across the life course. Journal of Personality 57:375-406.

Cheng, Helen, and Adrian Furnham. 2003. Personality, self-esteem, and demographic predictions of happiness and depression. Personality and Individual Differences 34:921-942.

Cheung, Felix, and Richard E. Lucas. 2014. Assessing the validity of single-item life satisfaction measures: results from three large samples. Quality of Life Research https://doi.org/10.1007/s11136-014-07264.

Christensen, P. Niels, Hank Rothgerber, Wendy Wood and David C. Matz. 2004. Social norms and identity relevance: a motivational approach to normative behavior. Personality and Social Psychology Bulletin 30:1295-1309.

Cialdini, Robert B., and Noah J. Goldstein. 2004. Social influence: compliance and conformity. Annual Review of Psychology 55:591-622.

Cialdini, Robert B., Raymond R. Reno and Carl A. Kallgren. 1990. A focus theory of normative conduct: recycling the concept of norms to reduce littering in public places. Journal of Personality and Social Psychology 58:1015-1026.

Cieciuch, Jan, Eldad Davidov, Peter Schmidt and René Algesheimer. 2019. How to obtain comparable measures for cross-national comparisons. In Cross-national comparative research-analytical strategies, results and explanations. Sonderheft Kölner Zeitschrift für Soziologie und Sozialpsychologie. Eds. Hans-Jürgen Andreß, Detlef Fetchenhauer and Heiner Meulemann. Wiesbaden: Springer VS. https:// doi.org/10.1007/s11577-019-00598-7.

Coleman, James S. 1990. Foundations of social theory. Cambridge: Harward University Press.

Correia, Isabel, Maria Toscano Batista and Maria Luisa Lima. 2009. Does the belief in a just world bring happiness? Causal relationships among belief in a just world, life satisfaction and mood. Australian Journal of Psychology 61:220-227.

Crocker, Jennifer, and Katherine M. Knight. 2005. Contingencies of self-worth. Current Directions in Psychological Science 14:200-203.

Cropanzano, Russell, and Thomas A. Wright. 1999. A 5-year study of change in the relationship between well-being and job performance. Consulting Psychology Journal: Practice and Research 51:252-265.

Danner, D. Deborah, David A. Snowdon and Wallce. V. Friesen. 2001. Positive emotions in early life and longevity: findings from the nun study. Journal of Personality and Social Psychology 80:804-813.

Deci, Edward L., and Richard M. Ryan. 2000. The 'what' and 'why' of goal pursuits: human needs and the self-determination of behavior. Psychological Inquiry 11:227-268.

Delle Fave, Antonella, Ingrid Brdar, Marié P. Wissing, Ulisses Araujo, Alejandro Castro Solano, Teresa Freire, María Del Rocío Hernández-Pozo, Paul Jose, Tamás Martos, Hilde E. Nafstad, Jeanne Nakamura, Kamlesh Singh and Lawrence Soosai-Nathan. 2016. Lay definitions of happiness across nations: the primacy of inner harmony and relational connectedness. Frontiers in Psychology. https:// doi.org/10.3389/fpsyg.2016.00030

Diener, Ed. 1984. Subjective well-being. Psychological Bulletin 95:542-575.

Diener, Ed, and Micaela Y. Chan. 2011. Happy people live longer: Subjective well-being contributes to health and longevity. Applied Psychology: Health and Well-Being 3:1-43. 
Diener, Ed, and Marissa Diener. 1995. Cross-cultural correlates of life satisfaction and self-esteem. Journal of Personality and Social Psychology 68:653-663.

Diener, Ed, and Katherine Ryan. 2009. Subjective well-being: a general overview. South African Journal of Psychology 39:391-406.

Diener, Ed, and Eunkook Suh. 2000. Culture and subjective well-being. Cambridge: A Bradford Book, The MIT Press.

Diener, Ed, Robert A. Emmons, Randy J. Larsen, and Sharon Griffin. 1985. The satisfaction with life scale. Journal of Personality Assessment 49:71-75.

Diener, Ed, Ronald Inglehart, and Louis Tay. 2013. Theory and validity of Life Satisfaction Scales. Social Indicators Research 112:497-527.

Diener, Ed, Weiting Ng, James Harter, and Raksha Arora. 2010. Wealth and happiness across the world: Material prosperity predicts life evaluation, whereas psychosocial prosperity predicts positive feeling. Journal of Personality and Social Psychology 99:52-61.

Diener, Ed, Shigehiro Oishi, and Richard E. Lucas. 2003. Personality, culture, and subjective well-being: emotional and cognitive evaluations of life. Annual Review of Psychology 54:403-425.

Diener, Ed, Eunkook M. Suh, Richard E. Lucas, and Heidi L. Smith. 1999. Subjective well-being: Three decades of progress. Psychological Bulletin 125:276-302.

Diener, Ed, Louis Tay, and David G. Myers. 2011. The religion paradox: if religion makes people happy, why are so many dropping out? Journal of Personality and Social Psychology 101:1278-1290.

Di Fabio, Annamaria, and Alessio Gori. 2016. Measuring adolescent life satisfaction: psychometric properties of the satisfaction with life scale in a sample of Italian adolescents and young adults. Journal of Psychoeducational Assessment 34:501-506.

Di Tella, Rafael, and Robert MacCulloch. 2006. Some uses of happiness data in economics. Journal of Economic Perspectives 20:25-25.

Di Tella, Rafael, Robert MacCulloch, and Andrew J. Oswald. 2003. The macroeconomics of happiness. The Review of Economics and Statistics 85:809-827.

Dorn, David, Justina A.V. Fischer, Gebhard Kirchgässner, and Alfonso Sousa-Poza. 2007. Is it culture or democracy? The impact of democracy and culture on happiness. Social Indicators Research 82:505-526.

Dulin, Patrick L., and R.D. Hill. 2003. Relationships between altruistic activity and positive and negative affect among low-income older adult service providers. Aging \& Mental Health 7:294-299.

Dunn, Elizabeth W., Lara B. Aknin, and Michael I. Norton. 2008. Spending money on others promotes happiness. Science 319:1687-1688.

Dunning, David, Heath Chip, and Jerry M. Suls. 2004. Flawed self-assessment: implications for health, education, and the workplace. Psychological Science in the Public Interest 5:69-106.

Eichhorn, Jan. 2014. The (non-)effect of unemployment benefits: variations in the effect of unemployment on life-satisfaction between EU countries. Social Indicators Research 119:389-404.

Elliot, Andrew, and Todd Thrash. 2002. Approach-avoidance motivation in personality approach and avoidance temperaments and goals. Journal of Personality and Social Psychology 82:804-818.

Elliot, Andrew, M. Sheldon Kenon, and Marcy A. Church. 1997. Avoidance personal goals and subjective well-being. Personality and Social Psychology Bulletin 23:915-927.

Feiler, Daniel C., and Adam M. Kleinbaum. 2015. Popularity, similarity, and the network extraversion bias. Psychological Science 26:593-603.

Florida, Richard, Charlotta Mellander, and Peter J. Rentfrow. 2013. The happiness of cities. Regional Studies 47:613-627.

Fredrickson, Barbara L. 2000. Extracting meaning from past affective experiences: the importance of peaks, ends, and specific emotions. Cognition and Emotion 14:577-606.

Fredrickson, Barbara L., and Christine Branigan. 2005. Positive emotions broaden the scope of attention and thought-action repertoires. Cognition \& Emotion 19:313-332.

Frey, Bruno, and Alois Stutzer. 2002a. Happiness and economics. How the economy and institutions affect well-being. Pinceton: Princeton University Press.

Frey, Bruno, and Alois Stutzer. 2002b. What can economists learn from happiness research? Journal of Economic Literature 40:402-435.

Frey, Bruno, and Alois Stutzer. 2005. Happiness research: state and prospects. Review of Social Economy 62:207-228.

Frey, Bruno, and Alois Stutzer. 2014. Economic consequences of mispredicting utility. Journal of Happiness Studies 15:937-956.

Gebauer, Jochen E., Constantine Sedikides, Felix D. Schonbrodt, Wiebke Bleidorn, P. Jason Rentfrow, J. Potter, and Sam D. Gosling. 2017. The religiosity as social value hypothesis: a multi-method replica- 
tion and extension across 65 countries and three levels of spatial aggregation. Journal of Personality and Social Psychology 113:e18-e39.

Glass, Jennifer, Robin W. Simon, and Matthew A. Andersson. 2016. Parenthood and happiness: effects of work-family reconciliation policies in 22 OECD countries. American Journal of Sociology 122:886-929.

Grunow, Daniela. 2019. Comparative analyses of housework and its relation to paid work: Institutional contexts and individual agency. In Cross-national comparative research - analytical strategies, results and explanations. Sonderheft Kölner Zeitschrift für Soziologie und Sozialpsychologie. Eds. Hans-Jürgen Andreß, Detlef Fetchenhauer and Heiner Meulemann. Wiesbaden: Springer VS. https://doi.org/ 10.1007/s11577-019-00601-1.

Hammond, Matthew, and Chris Sibley. 2011. Why are benevolent sexists happier? Sex Roles 65:332-343.

Hank, Karsten, and Anja Steinbach. 2019. Families and their institutional contexts: The role of family policies and legal regulations. In Cross-national comparative research-analytical strategies, results and explanations. Sonderheft Kölner Zeitschrift für Soziologie und Sozialpsychologie. Eds. HansJürgen Andreß, Detlef Fetchenhauer and Heiner Meulemann. Wiesbaden: Springer VS. https://doi. org/10.1007/s11577-019-00603-z.

Hayes, Natalie, and Stephen Joseph. 2003. Big 5 correlates of three measures of subjective well-being. Personality and Individual Differences 34:723-727.

Headey, Bruce, and A. Wearing. 1992. Understanding happiness: a theory of subjective well-being. Melbourne: Longman Cheshire.

Heine, Steven J., and Takeshi Hamamura. 2007. In search of East Asian self-enhancement. Personality and Social Psychology Review 11:1-24.

Heizmann, Boris, and Petra Böhnke. 2018. Immigrant life satisfaction in Europe: the role of social and symbolic boundaries. Journal of Ethnic and Migration Studies. https://doi.org/10.1080/1369183X. 2018.1438252

Henrich, Joseph, Steven J. Heine, and Ara Norenzayan. 2010. The weirdest people in the world? Behavioral \& Brain Sciences 33:61-135.

Hill, Patrick L., and Nicholas A. Turiano. 2014. Purpose in life as a predictor of mortality across adulthood. Psychological Science 25:1482-1486.

Hofmann, Wilhelm, Maike Luhmann, Rachel R. Fisher, Kathleen D. Vohs, and Roy F. Baumeister. 2014. Yes, but are they happy? Effects of trait self-control on affective well-being and life satisfaction. Journal of Personality 82:265-277.

Hofstede, Geert. 2001. Culture's consequences: comparing values, behaviors, institutions and organizations across nations. London: SAGE.

Hox, Joop. 2002. Multilevel analysis: techniques and applications. New Jersey: Lawrence Erlbaum.

Joshanloo, Mohsen, and Aaron Jarden. 2016. Individualism as the moderator of the relationship between hedonism and happiness: a study in 19 nations. Personality and Individual Differences 94:149-152.

Joshanloo, Mohsen, Zarina K. Lepshokova, Tatiana Panyusheva, Natalia Amerkhanova, Wai-Ching Poon, Victoria Wai-lan Yeung, Suresh Sundaram, Mustapha Achoui, Ryosuke Asano, Tasuku Igarashi, Saori Tsukamoto, Muhammad Rizwan, Imran Ahmed Khilji, Maria Cristina Ferreira, Joyce S. Pang, Lok Sang Ho, Gyuseog Han, Jaechang Bae, and Ding-Yu Jiang. 2014. Cross-cultural validation of fear of happiness scale across 14 national groups. Journal of Cross-Cultural Psychology 45:246-264.

Jovanović, Veljko. 2016. The validity of the satisfaction with life scale in adolescents and a comparison with single-item life satisfaction measures: a preliminary study. Quality of Life Research: An International Journal of Quality of Life Aspects of Treatment, Care \& Rehabilitation 25:3173-3180.

Kahneman, Daniel. 2000. Experienced utility and objective happiness: a moment-based approach. In Choices, values and frames, ed. Daniel Kahneman, Amos Tversky, 673-692. New York: Cambridge University Press.

Kahneman, Daniel, and Angus Deaton. 2010. High income improves evaluation of life but not emotional well-being. Proceedings of the National Academy of Sciences 107:16489-16493.

Kasser, Tim, and Richard M. Ryan. 1993. A dark side of the American dream: correlates of financial success as a central life aspiration. Journal of Personality and Social Psychology 65:410-422.

Kim, Hyoun, and Patrick C. MacKenry. 2002. The relationship between marriage and psychological wellbeing: a longitudinal analysis. Journal of Family Issues 23:885-911.

Kogan, Irena, Jing Shen, and Manuel Siegert. 2017. What makes a satisfied immigrant? Host-country characteristics and immigrants' life satisfaction in eighteen European countries. Journal of Happiness Studies 19:1783-1809.

Kööts-Ausmees, Liisi, and Anu Realo. 2015. The association between life satisfaction and self-reported health status in Europe. European Journal of Personality 29:647-657. 
Kristof-Brown, Amyl, Ryan D. Zimmerman, and Erin C. Johnson. 2005. Consequences of individuals' fit at work: a meta-analysis of person-job, person-organization, person-group, and person-supervisor fit. Personnel Psychology 58:281-342.

Lachman, Margie E., and Stefan Agrigoroaei. 2010. Promoting functional health in midlife and old age: Long-term protective effects of control beliefs, social support, and physical exercise. PLoS ONE. https://doi.org/10.1371/journal.pone.0013297

Lim, Young-Jin. 2015. Psychometric characteristics of the Korean version of the Satisfaction With Life Scale adapted for children. Canadian Journal of School Psychology 30:246-251.

Lim, Chaeyoon, and Robert D. Putnam. 2009. Praying alone is no fun: religion, social networks, and subjective well-being. In Paper presented at the meeting of the Canadian Institute for Advanced Research. Toronto, Ontario: Institute for Advanced Research.

Liu, Pan, William Tov, Michal Kosinski, David J. Stillwell, and Lin Qiu. 2015. Do Facebook status updates reflect subjective well-being? Cyberpsychology, Behavior, and Social Networking 18:373-379.

de Looze, Margaretha E., Tim Huijts, Gonneke Stevens, Torbjorn Torsheim, and Wilma Vollebergh. 2017. The happiest kids on earth. Gender equality and adolescent life satisfaction in Europe and North America. Journal of Youth and Adolescence 47:1073-1085.

Lucas, Richard. 2007. Adaptation and the set-point model of subjective well-being: does happiness change after major life events? Current Directions in Psychological Science 16:75-79.

Lucas, Richard E., and Portia S. Dyrenforth. 2006. Does the existence of social relationships matter for subjective well-being? In Self and relationships: Connecting intrapersonal and interpersonal processes, ed. Kathleen D. Vohs, Eli J. Finkel, 254-273. New York: Guilford.

Lucas, Richard, A. Clark, Yannis Georgellis, and E. Diener. 2004. Unemployment alters the set point for life satisfaction. Psychological Science 15:8-13.

Lucas, Todd, Ludmila Zhdanova, Craig Wendorf, and Sheldon Alexander. 2013. Procedural and distributive justice beliefs for self and others: multilevel associations with life satisfaction and self-rated health. Journal of Happiness Studies 14:1325-1341.

Lucas, Richard E., Ed Diener, Alexander Grob, Eunkook M. Suh, and Liang Shao. 2000. Cross-cultural evidence for the fundamental features of extraversion. Journal of Personality and Social Psychology 79:452-468.

Luhmann, Maike, Wilhelm Hofmann, Michael Eid, and Richard Lucas. 2012. Subjective well-being and adaptation to life events: a meta-analysis. Journal of Personality and Social Psychology 102:592-615.

Luhmann, Maike, Richard E. Lucas, Michael Eid, and E. Diener. 2013. The prospective effect of life satisfaction on life events. Social Psychological and Personality Science 4:39-45.

Luhmann, Maike, Ulrich Schimmack, and Michael Eid. 2011. Stability and variability in the relationship between subjective well-being and income. Journal of Research in Personality 45:186-197.

Lykken, David, and Auke Tellegen. 1996. Happiness is a stochastic phenomenon. Psychological Science 7:186-189

Lyubomirsky, Sonja, and Heidi S. Lepper. 1999. A measure of subjective happiness: preliminary reliability and construct validation. Social Indicators Research 46:137-155.

Lyubomirsky, Sonja, M. Kennon Sheldon, and David Schkade. 2005b. Pursuing happiness: the architecture of sustainable change. Review of General Psychology 9:111-131.

Lyubomirsky, Sonja, Laura King, and Ed Diener. 2005a. The benefits of frequent positive affect: does happiness lead to success? Psychological Bulletin 131:803-855.

López-Ortega, Mariana, Sara Torres-Castro, and Oscar Rosas-Carrasco. 2016. Psychometric properties of the satisfaction with life scale (SWLS): secondary analysis of the Mexican Health and Aging Study. Health and Quality of Life Outcomes. https://doi.org/10.1186/s12955-016-0573-9

Markus, Hazel R., and Shinobu Kitayama. 1991. Culture and the self: implications for cognition, emotion, and motivation. Psychological Review 98:224-253.

Maslow, Abraham H. 1943. A theory of human motivation. Psychological Review 50:380-396.

McMahon, Darrin M. 2006. Happiness: A history. New York: Atlantic Monthly Press.

Mesquita, Batja, and Mayumi Karasawa. 2002. Different emotional lives. Cognition and Emotion 16:127-141.

Moor, Nienke, Paul M. de Graaf, and Aafke Komter. 2013. Family, welfare state generosity and the vulnerability of older adults: a cross-national study. Journal of Aging Studies 27:347-357.

Napier, Jaime L., and John T. Jost. 2008. Why are conservatives happier than liberals? Psychological Science 19:565-572.

Neuberger, Franz Stephan, and Klaus Preisner. 2017. Parenthood and quality of life in old age: the role of individual resources, the welfare state and the economy. Social Indicators Research. https://doi.org/ $10.1007 / \mathrm{s} 11205-017-1665-6$ 
Niedzwiedz, Claire L., Jill P. Pell, and Richard Mitchell. 2015. The relationship between financial distress and life-course socioeconomic inequalities in well-being: cross-national analysis of European welfare states. American Journal of Public Health 105:2090-2098.

Noelle-Neumann, Elizabeth. 1974. The spiral of silence: a theory of public opinion. Journal of Communication 24:43-51.

Oarga, Cristina, Olga Stavrova, and Detlef Fetchenhauer. 2015. When and why is helping others good for well-being? The role of belief in reciprocity and conformity to society's expectations. European Journal of Social Psychology 45:242-254.

Ochsen, Carsten, and Heinz Welsch. 2012. Who benefits from labor market institutions? Evidence from surveys of life satisfaction. Journal of Economic Psychology 33:112-124.

Oishi, Shigehiro. 2002. The experiencing and remembering of well-being: a cross-cultural analysis. Personality and Social Psychology Bulletin 28:1398-1406.

Oishi, Shigehiro, Jesse Graham, Selin Kesebir, and Iolanda Costa Galinha. 2013. Concepts of happiness across time and cultures. Personality and Social Psychology Bulletin 39:559-577.

Oishi, Shigehiro, Selin Kesebir, and Ed Diener. 2011. Income inequality and happiness. Psychological Science 22:1095-1100.

Oishi, Shigehiro, Selin Kesebir, and Benjamin H. Snyder. 2009. Sociology: a lost connection in social psychology. Personality and Social Psychology Review 13:334-353.

Oishi, Shigehiro, Ed Diener, Richard Lucas, and Eunkook Suh. 1999. Cross-cultural variations in predictors of life satisfaction: Perspectives from needs and values. Personality and Social Psychology Bulletin 25:980-990.

Ormel, Johan, Siegwart Lindenberg, Nardi Steverink, and Lois M. Verbrugge. 1999. Subjective well-being and social production functions. Social Indicators Research 46:61-90.

Orth, Ulrich, and Eva C. Luciano. 2015. Self-esteem, narcissism, and stressful life events: testing for selection and socialization. Journal of Personality and Social Psychology 109:707-721.

Ott, Jan. 2011. Government and happiness in 130 nations: good governance fosters higher level and more equality of happiness. Social Indicators Research 102:3-22.

Ouwerkerk, Jaap W., Norbert L. Kerr, Marcello Gallucci, and Paul A.M. van Lange. 2005. Avoiding the social death penalty: ostracism and cooperation in social dilemmas. In The social outcast, ed. D. Williams Kipling, Joseph P. Forgas, and William von Hippel, 321-332. New York: Psychology Press.

Oyserman, Daphna, Heather M. Coon, and Markus Kemmelmeier. 2002. Rethinking individualism and collectivism: evaluation of theoretical assumptions and meta-analyses. Psychological Bulletin 128:3-72.

Pavot, William, and Ed Diener. 1993. Review of the satisfaction with life scale. Psychological Assessment 5:164-172.

Pavot, William, and Ed Diener. 2008. The Satisfaction With Life Scale and the emerging construct of life satisfaction. The Journal of Positive Psychology 3:137-152.

Pförtner, Timo-Kolja, Holger Pfaff and Frank J. Elgar. 2019. The role of welfare state characteristics for health and inequalities in health from a cross-national perspective: A critical research synthesis. In Cross-national comparative research - analytical strategies, results and explanations. Sonderheft Kölner Zeitschrift für Soziologie und Sozialpsychologie. Eds. Hans-Jürgen Andreß, Detlef Fetchenhauer and Heiner Meulemann. Wiesbaden: Springer VS. https://doi.org/10.1007/s11577-019-00606w.

Plomin, Robert. 1994. Genetics and experience: the interplay between nature and nurture. London: SAGE.

Pool, Gregory J., Wendy Wood, and Kira Leck. 1998. The self-esteem motive in social influence: agreement with valued majorities and disagreement with derogated minorities. Journal of Personality and Social Psychology 75:967-975.

Redelmeier, Donald A., and Daniel Kahneman. 1996. Patients' memories of painful medical treatments: real-time and retrospective evaluations of two minimally invasive procedures. Pain 66:3-8.

Reitz, Anne K., Frosso Motti-Stefanidi, and Jens B. Asendorpf. 2016. Me, us, and them: testing sociometer theory in a socially diverse real-life context. Journal of Personality and Social Psychology 110:908-920.

Rentfrow, Peter Jason, Samuel D. Gosling, and Jeff Potter. 2008. A theory of the emergence, persistence, and expression of geographic variation in psychological characteristics. Perspectives on Psychological Science 3:339-369.

Rentfrow, Peter Jason, Charlotta Mellander, and Richard Florida. 2009. Happy states of america: a statelevel analysis of psychological, economic, and social well-being. Journal of Research in Personality 43:1073-1082.

Roex, Karlijn L.A., and Jesper J. Rözer. 2018. The social norm to work and the well-being of the shortand long-term unemployed. Social Indicators Research 139:1037-1064. 
Rose, Damaris, and Olga Stavrova. 2019. Does life satisfaction predict reemployment? Evidence form German panel data. Journal of Economic Psychology 72:1-11.

Ross, Michael, and Wang Qi. 2010. Why we remember and what we remember: culture and autobiographical memory. Perspectives on Psychological Science (Sage Publications Inc.) 5:401-409.

Ross, Michael, and Anne E. Wilson. 2002. It feels like yesterday: self-esteem, valence of personal past experiences, and judgments of subjective distance. Journal of Personality and Social Psychology 82:792-803.

Rudman, Laurie A., and Kimberly Fairchild. 2004. Reactions to counterstereotypic behavior: the role of backlash in cultural stereotype maintenance. Journal of Personality and Social Psychology 87:157-176.

Ryan, Richard M., and Edward L. Deci. 2000. Self-determination theory and the facilitation of intrinsic motivation, social development, and well-being. American Psychologist 55:68-78.

Ryan, Richard M., and Edward L. Deci. 2001. On happiness and human potential: a review of research on hedonic and eudaimonic well-being. Annual Review of Psychology 52:141-166.

Ryff, Carol D. 1989. Happiness is everything, or is it? Explorations on the meaning of psychological wellbeing. Journal of Personality and Social Psychology 57:1069-1081.

Sagiv, Lilach, and Shalom H. Schwartz. 2000. Value priorities and subjective well-being: direct relations and congruity effects. European Journal of Social Psychology 30:177-198.

Schimmack, Ulrich, and Shigehiro Oishi. 2005. The influence of chronically and temporarily accessible information on life satisfaction judgments. Journal of Personality and Social Psychology 89:395-406.

Schmidt-Catran, Alexander W., Malcolm Fairbrother and Hans-Jürgen Andreß. 2019. Multilevel models for the analysis of comparative survey data: Common problems and some solutions. In Cross-national comparative research - analytical strategies, results and explanations. Sonderheft Kölner Zeitschrift für Soziologie und Sozialpsychologie. Eds. Hans-Jürgen Andreß, Detlef Fetchenhauer and Heiner Meulemann. Wiesbaden: Springer VS. https://doi.org/10.1007/s11577-019-00607-9.

Schneider, Leann, and Ulrich Schimmack. 2010. Examining sources of self-informant agreement in lifesatisfaction judgments. Journal of Research in Personality 44:207-212.

Schwartz, Shalom H. 1992. Universals in the content and structure of values: theory and empirical tests in 20 countries. In Advances in experimental social psychology, ed. M. Zanna, 1-65. New York: Academic Press.

Schwartz, Carolyn, Janice Bell Meisenhelder, Ma Yunsheng, and George Reed. 2003. Altruistic social interest behaviors are associated with better mental health. Psychosomatic Medicine 65:778-785.

Schwarz, Norbert. 1990. Feelings as information: Informational and motivational functions of affective states. In Handbook of motivation and cognition, ed. E. Tory Higgings, Richard M. Sorrentino, 527-561. New York: Guilford.

Schyns, Peggy. 2002. Wealth of nations, individual income and life satisfaction in 42 countries: a multilevel approach. Social Indicators Research 60:5-40.

Seligman, Martin. 2002. Authentic happiness: using the new positive psychology to realize your potential for lasting fulfillment. New York: Free Press.

Settanni, Michele, and Davide Marengo. 2015. Sharing feelings online: studying emotional well-being via automated text analysis of Facebook posts. Frontiers in Psychology. https://doi.org/10.3389/fpsyg. 2015.01045

Sheldon, Kennon M., and T. Kasser. 1998. Pursuing personal goals: skills enable progress, but not all goal progress is beneficial. Personality and Social Psychology Bulletin 24:1319-1331.

Silva, Ana Daniela, Maria do Céu Taveira, Cátia Marques, and Valdiney V. Gouveia. 2015. Satisfaction with life scale among adolescents and young adults in Portugal: extending evidence of construct validity. Social Indicators Research 120:309-318.

Sortheix, Florencia M., and Shalom H. Schwartz. 2017. Values that underlie and undermine well-being: variability across countries. European Journal of Personality 31:187-201.

Specht, Jule, Boris Egloff, and Stefan C. Schmukle. 2013. Examining mechanisms of personality maturation: the impact of life satisfaction on the development of the big five personality traits. Social Psychological and Personality Science 4:181-189.

Stavrova, Olga. 2014. Fitting in and getting happy: How conformity to societal norms affects subjective well-being. Frankfurt a. M.: Campus.

Stavrova, Olga. 2015a. How regional personality affects individuals' life satisfaction: a case of emotional contagion? Journal of Research in Personality 58:1-5.

Stavrova, Olga. 2015b. Religion, self-rated health, and mortality. Social Psychological and Personality Science 6:911-922. 
Stavrova, Olga. 2019. Having a happy spouse is associated with lowered risk of mortality. Psychological Science 25:2189-2198. https://doi.org/10.1177/0956797619835147.

Stavrova, Olga, and Detlef Fetchenhauer. 2015a. Married and cohabiting parents' well-being: the effects of a cultural normative context across countries. Journal of Social and Personal Relationships 32:601-632.

Stavrova, Olga, and Detlef Fetchenhauer. 2015b. Single parents, unhappy parents? Parenthood, partnership and the cultural normative context. Journal of Cross-Cultural Psychology 46:134-149.

Stavrova, Olga, and Maike Luhmann. 2016a. Are conservatives happier than liberals? Not always and not everywhere. Journal of Research in Personality 63:29-35.

Stavrova, Olga, and Maike Luhmann. 2016b. Social connectedness as a source and consequence of meaning in life. The Journal of Positive Psychology 11:470-479.

Stavrova, Olga, Daniel Ehlebracht, and Detlef Fetchenhauer. 2016. Belief in scientific-technological progress and life satisfaction: the role of personal control. Personality and Individual Differences 96:227-236.

Stavrova, Olga, Detlef Fetchenhauer and Thomas Schlösser. 2012. Cohabitation, gender, and happiness: a cross-cultural study in thirty countries. Journal of Cross-Cultural Psychology 43:1063-1081.

Stavrova, Olga, Detlef Fetchenhauer and Thomas Schlösser. 2013a. Why are religious people happy? The effect of the social norm of religiosity across countries. Social Science Research 42:90-105.

Stavrova, Olga, Thomas Schlösser, and Detlef Fetchenhauer. 2011. Are the unemployed equally unhappy all around the world? The role of the social norms to work and welfare state provision in 28 OECD countries. Journal of Economic Psychology 32:159-171.

Stavrova, Olga, Thomas Schlösser, and Detlef Fetchenhauer. 2013b. Are virtuous people happy all around the world? Civic virtue, antisocial punishment, and subjective well-being across cultures. Personality and Social Psychology Bulletin 39:927-942.

Steel, Piers, and Deniz S. Ones. 2002. Personality and happiness: a national-level analysis. Journal of Personality and Social Psychology 83:767-781.

Steel, Piers, Joseph Schmidt, and Jonas Shultz. 2008. Refining the relationship between personality and subjective well-being. Psychological Bulletin 134:138-161.

Steger, Michael. 2014. Is it time to consider meaning in life as a public policy priority? Ewha Journal of Social Sciences. https://ssrn.com/abstract=2580707

Stevenson, Betsey, and Justin Wolfers. 2009. The paradox of declining female happiness. American Economic Journal: Economic Policy 1:190-225.

Suh, Eunkook, Ed Diener, Shigehiro Oishi, and Harry C. Triandis. 1998. The shifting basis of life satisfaction judgments across cultures: Emotions versus norms. Journal of Personality and Social Psychology 74:482-493.

Suldo, Shannon, Devon Minch, and Brittany Hearon. 2015. Adolescent life satisfaction and personality characteristics: investigating relationships using a five factor model. Journal of Happiness Studies 16:965-983.

Tajfel, Henri, M.G. Billig, R.P. Bundy, and Claude Flament. 1971. Social categorization and intergroup behaviour. European Journal of Social Psychology 1:149-178.

Tay, Louis, Mitchel N. Herian, and Ed Diener. 2014. Detrimental effects of corruption and subjective wellbeing: Whether, how, and when. Social Psychological and Personality Science 5:751-759.

Tesch-Roemer, Clemens, Andreas Motel-Klingebiel, and Martin J. Tomasik. 2008. Gender differences in subjective well-being: comparing societies with respect to gender equality. Social Indicators Research 85:329-349.

Tokuda, Yasuharu, Seiji Fujii, and Takashi Inoguchi. 2010. Individual and country-level effects of social trust on happiness: the Asia Barometer Survey. Journal of Applied Social Psychology 40:2574-2593.

Triandis, H.C. 1995. Individualism and collectivism. Boulder: Westview.

Uchida, Yukiko, and Shinobu Kitayama. 2009. Happiness and unhappiness in east and west: themes and variations. Emotion 9:441-456.

Veenhoven, Ruut. 1984. Conditions of happiness. Dordrecht: Reidel Publ. Co.

Veenhoven, Ruut. 1993. Happiness in nations: Subjective appreciation of life in 56 nations 1946-1992. Rotterdam: Erasmus University.

Veenhoven, Ruut. 2008. Sociological theories of subjective well-being. In The science of subjective wellbeing: a tribute to Ed Diener, ed. Michael Eid, Randy Larsen, 44-61. New York: Guilford.

Veenhoven, Ruut. 2012. Cross-national differences in happiness: cultural measurement bias or effect of culture? International Journal of Wellbeing 2:333-353. https://doi.org/10.5502/ijw.v2.i4.4

Veenhoven, Ruut, and Yowon Choi. 2012. Does intelligence boost happiness? Smartness of all pays more than being smarter than others. International Journal of Happiness and Development 1:5-27. 
Van de Velde, Sarah, Koen Van der Bracht, and Veerle Buffel. 2017. The relation between religion and depression in Europe: the moderating role of the religious context. International Journal of Comparative Sociology 58:515-532.

Voßemer, Jonas, Michael Gebel, Kadri Täht, Marge Unt, Björn Högberg, and Mattias Strandh. 2017. The effects of unemployment and insecure jobs on well-being and health: the moderating role of labor market policies. Social Indicators Research. https://doi.org/10.1007/s11205-017-1697-y

Wallace, John M., and Tyrone A. Forman. 1998. Religion's role in promoting health and reducing risk among American youth. Health Education \& Behavior 25:721-741.

Watson, Deryn, A. Clark Lee, and Auke Tellegen. 1988. Development and validation of brief measures of positive and negative affect: the PANAS Scale. Journal of Personality and Social Psychology 54:1063-1070.

Weinstein, Neil D. 1980. Unrealistic optimism about future life events. Journal of Personality \& Social Psychology 39:806-820.

Whisman, Mark A., and Charles M. Judd. 2016. A cross-national analysis of measurement invariance of the Satisfaction With Life Scale. Psychological Assessment 28:239-244.

Williams, Kipling D. 2007. Ostracism. Annual Review of Psychology 58:425-452.

Williams, Kristi, and Alexandra Dunne-Bryant. 2006. Divorce and adult psychological well-being: clarifying the role of gender and child age. Journal of Marriage and Family 68:1178-1196.

Williams, Kipling D., Christopher K.T. Cheung, and Wilma Choi. 2000. Cyberostracism: effects of being ignored over the Internet. Journal of Personality and Social Psychology 79:748-762.

Wilson, Warner R. 1967. Correlates of avowed happiness. Psychological Bulletin 67:294-306.

Wood, Wendy, P. Niels Christensen, Michelle R. Hebl, and Hank Rothgerber. 1997. Conformity to sextyped norms, affect, and the self-concept. Journal of Personality and Social Psychology 73:523-535.

Yap, Stevie C.Y., Jessica Wortman, Ivana Anusic, S. Glenn Baker, Laura D. Scherer, M. Brent Donnellan, and Richard E. Lucas. 2016. The effect of mood on judgments of subjective well-being: nine tests of the judgment model. Journal of Personality and Social Psychology 113:939-961.

Olga Stavrova 1985, Dr. rer.pol., Assistant Professor at Tilburg University (The Netherlands). Areas of research: social psychology, personality psychology. Publications: Cynical beliefs about human nature and income: longitudinal and cross-cultural analyses. Journal of Personality and Social Psychology 110, 2015 (with D. Ehlebracht); Having a happy spouse is associated with lowered risk of mortality. Psychological Science 2019; Fitting in and getting happy. How conformity to societal norms affects subjective wellbeing. Frankfurt a. M. 2014. 